\title{
Phosphonium ionic liquids: design, synthesis and evaluation of biodegradability $\dagger$
}

\author{
Farzad Atefi, ${ }^{a}$ M. Teresa Garcia, ${ }^{* b}$ Robert D. Singer ${ }^{* c}$ and Peter J. Scammells ${ }^{* a}$
}

\author{
Received 30th April 2009, Accepted 10th June 2009 \\ First published as an Advance Article on the web 21st July 2009 \\ DOI: 10.1039/b913057h
}

\begin{abstract}
The biodegradability of a range of phosphonium ionic liquids (ILs) was assessed using the $\mathrm{CO}_{2}$ headspace test (ISO 14593). Tetraalkylphosphonium cations in which one of the alkyl substituents contained ester, ether, alcohol or alkene functionality in order to promote biodegradation were targeted. These cations were paired with halide, triflimide and octylsulfate anions. In contrast to previously studied dialkylimidazolium and alkylpridinium ILs with incorporated ester moieties and octylsulfate anions, the phosphonium ILs showed relatively low levels of biodegradability.
\end{abstract}

\section{Introduction}

The first generation of ionic liquids (ILs) date back to an observation of Paul Walden in 1914, who reported the properties of ethylammonium nitrate, considered to be the first IL. ${ }^{1}$ The current definition if ILs is still derived from this initial article, essentially defining them as ionic materials which melt below $100{ }^{\circ} \mathrm{C}$. Most ILs reported before 1992 contain haloaluminates as counter-ions, making them air and water sensitive and therefore of little value to industrial applications. ${ }^{2}$ This changed drastically when Wilkes and Zaworotko reported air and water stable ILs with alternative anions, such as $\mathrm{BF}_{4}{ }^{-} \cdot{ }^{3}$ These so called second generation ILs, can now be easily prepared and have opened the door for a wide range of possible applications. The number of articles published in this field has grown almost exponentially since the early 1990's and in 2008 alone more than 2500 reports can be found on ILs. ${ }^{4}$ Their excellent thermal and chemical stability, as well as the ease of recycling, make ILs today very attractive for industrial applications. In 2002 BASF publicly announced an industrial process which uses ILs on a multi-ton scale. ${ }^{5}$ Since then many other processes by companies such as Degussa, BP and Linde have followed. ${ }^{6}$ The scope of their applications, include materials for dye sensitised solar cells, ${ }^{7}$ extraction media for metals, ${ }^{8}$ electrolytes for electrochemical storage devices ${ }^{9}$ and solvents in separation sciences. ${ }^{10}$ In synthetic chemistry ILs were initially renowned for their special solubility characteristics, which favour transition metal catalysed reactions ${ }^{11}$ and multi phasic reaction systems. ${ }^{12}$

${ }^{a}$ Medicinal Chemistry and Drug Action, Monash Institute of Pharmaceutical Sciences, Monash University, Parkville 3052, Victoria, Australia. E-mail: peter.scammells@pharm.monash.edu.au; Fax: +61 3 99039582; Tel: +61399039542

${ }^{b}$ Department of Surfactant Technology, IQAC-CSIC, Jordi Girona 18-26,08034, Spain. E-mail: mtgbet@iiqab.csic.es; Fax: +34 93204 5904; Tel: +34934006100

'Department of Chemistry, Saint Mary's University, Halifax, Nova Scotia,B3H 3C3, Canada.E-mail: robert.singer@smu.ca; Fax: +1 902 496 8104; Tel: +19024968189

+ Electronic supplementary information (ESI) available: ${ }^{1} \mathrm{H},{ }^{13} \mathrm{C}$ and ${ }^{31} \mathrm{P}$ NMR spectra of all novel phosphonium ionic liquids. See DOI: $10.1039 /$ b913057h
In recent years however ILs have emerged as a viable alternative to traditional solvents in a variety of stoichiometric and acid catalysed traditional organic reactions, including the DielsAlder, Friedel-Crafts and Michael protocols, to name just a few. ${ }^{13}$

Many authors describe ILs as "greener" alternatives to common organic solvents, since they usually display no measurable vapour pressure and are non-flammable, therefore eliminating the safety and environmental problems often associated with volatile organic solvents. ${ }^{14}$ However a multidimensional risk analysis, as described by the Jastorff group, is necessary in order to assess the environmental sustainability of ILs. ${ }^{15}$ These authors proposed that the environmental impact of ILs depends on five ecotoxicological indicators: release, spatiotemporal range, bioaccumulation, biological activity and uncertainty. Due to the lack of experimental data on the toxicology and biodegradability of ILs, there is unfortunately a high uncertainty level on their environmental impact. It has been well established that the release of non-biodegradable organic substances into the environment, even when non-toxic, can lead to bioaccumulation which in turn might result in chronic toxic effects. ${ }^{16}$ The biodegradation pathway on the other hand, which ultimately leads to the formation of non-toxic products such as $\mathrm{CO}_{2}$, water and biomass, seems to be the cleanest fate of any chemical released into the environment.

We centred our initial investigations into the biodegradability of ILs around the commonly used imidazolium cation and found linear alkyl chains and amide functionality result in poor or negligible biodegradation, while ester side chains result in a significant enhancement of biodegradation. ${ }^{17}$ The effect of the anions have also been studied and, as suggested, ${ }^{18}$ we discovered biodegradability increases by incorporating the organic octylsulfate anion. ${ }^{19}$ The first readily biodegradable ILs were reported in 2006 and contain an imidazolium cation with propyl or pentyl ester side chains together with an octylsulfate anion. ${ }^{20}$ These ILs have also been successfully utilised as reaction media for DielsAlder reactions and palladium-catalysed hydrogenations. ${ }^{21}$ Our findings have been confirmed by a Spanish group, who also reported that the toxicity of linear alkyl chain imidazolium ILs increases with the chain length. ${ }^{22}$ 
Docherty et al. compared the biodegradation of imidazolium and pyridinium ionic liquids and evaluated only the cations with different alkyl chains. Their findings concluded that pyridinium ILs are generally more environmentally friendly. ${ }^{23}$ Stolte and co-workers also compared these two IL cations and proposed a biodegradation pathway for imidazolium ILs. It has been realised that a certain lipophilicity is an important criterion for biodegradable IL cations. Unfortunately, higher lipophilicity can result in increased toxicity, leading to a bottle-neck for the design of benign ILs. ${ }^{24}$ Our group evaluated the biodegradability of a large series of pyridinium ILs with ester functionality and compared them with pyridinium ILs containing only alkyl side chains. ${ }^{25}$ Again the ILs with ester side chains proved to be readily biodegradable, however we also noticed a higher tendency of decay for pyridinium ILs in general. Even lipophilic anions, like the bis(trifluoromethanesulfonamide) anion (triflimide) do not reduce the biodegradability of pyridinium ILs significantly. The viability of these ILs as reaction media for Diels-Alder reactions $^{25 \mathrm{~b}}$ and for the RAFT mediated polymerisation of styrene ${ }^{26}$ has also been demonstrated. One pyridinium IL with an ester side chain and a sacharinate anion was also identified as readily biodegradable. ${ }^{27}$ In addition, Yun and co-workers have proposed a potential biodegradation pathway for pyridinium ILs. $^{28}$ Very recently we have revisited our initial interest in the biodegradability of imidazolium ILs. Unfortunately none of the variety of different functional groups we attached to the imidazolium cation lead to readily biodegradable ILs. Different anions have also been tested and it was found that the lactate anion coupled with an imidazolium cation bearing a pentyl ester in the side chain has similar biodegradability values as the same cation coupled with the octylsulfate anion. Increasing the chain length of the sulfate anion also increases the biodegradability of ILs. ${ }^{29}$ Biodegradable naphthenic acid ILs have also been reported, but unfortunately they have a low thermal stability compared to commonly used ILs. ${ }^{30}$

Phosphonium ionic liquids (PILs) have some advantages over imidazolium and pyridinium ILs. They are thermally more stable and the kinetics of the salt formation is faster. PILs have also no acidic proton, which makes them stable towards nucleophilic and basic conditions, and they have a lower density than water, which provides potential benefits for some applications. ${ }^{31}$ Due to our general interest in the biodegradation if ILs, we decided to systematically study the decay of a large panel of PILs with different functional groups attached to the cation and different anions. The biodegradation of PILs has been tested only once so far, but only two commercially available PILs with linear alkyl chains were evaluated. ${ }^{32}$ Unsurprisingly both show almost no tendency towards biodegradation, simply because they are highly toxic to the microorganisms responsible for biodegradation. We based the design of the PILs for testing on our previous success with ester side chains as well as other proposed biodegradation enhancers, such as the introduction of oxygen. ${ }^{33}$ We included the octylsulfate anion as well as the lipophilic triflimide anion which, due to its low viscosity, is very convenient to handle.

All PILs were assessed by the $\mathrm{CO}_{2}$ headspace test (ISO 14593 , OECD 310). These biodegradability tests were conducted under stringent conditions of high concentration of test substance, as the only source of carbon for the microorganisms, and low microbial density. A substance can be classified as readily biodegradable, when at least $60 \%$ of the theoretical possible $\mathrm{CO}_{2}$ is liberated within the first 28 days of incubation and a positive result is considered to correspond with rapid degradation in most aqueous environments.

\section{Results and discussion}

The first set of designer PILs evaluated in this study contained a tricyclohexylphosphine based cation with various ester side chains. The ILs were formed in a typical alkylation reaction with the appropriate $\alpha$-haloester to obtain the desired phosphonium halide (Scheme 1). ${ }^{31 a}$ The reactions were carried out without solvent at $90^{\circ} \mathrm{C}$, which is slightly higher than the melting point of tricyclohexylphosphine $\left(78^{\circ} \mathrm{C}\right)$ and ensures a homogenous reaction mixture. ILs 2a-5a were obtained after recrystallisation in good to excellent yields of $55-92 \%$ as gels, which all melt below $50{ }^{\circ} \mathrm{C}$. Metathesis reactions with lithium triflimide or ammonium octylsulfate resulted in the PILs $\mathbf{2 b}-\mathbf{5 b}$ and $\mathbf{2 c - 5 c}$ respectively in excellent yields of $89-98 \%$. Since the iodide salt $\mathbf{5 a}$ has low water solubility, the reactions resulting in $\mathbf{5 b}$ and $\mathbf{5 c}$ were carried out in water $/ \mathrm{MeOH}$. All metathesis products were tested with $\mathrm{AgNO}_{3}$ for halide residues and are liquids at room temperature, except $\mathbf{2 b}$ which is waxy and melts below $50{ }^{\circ} \mathrm{C}$.

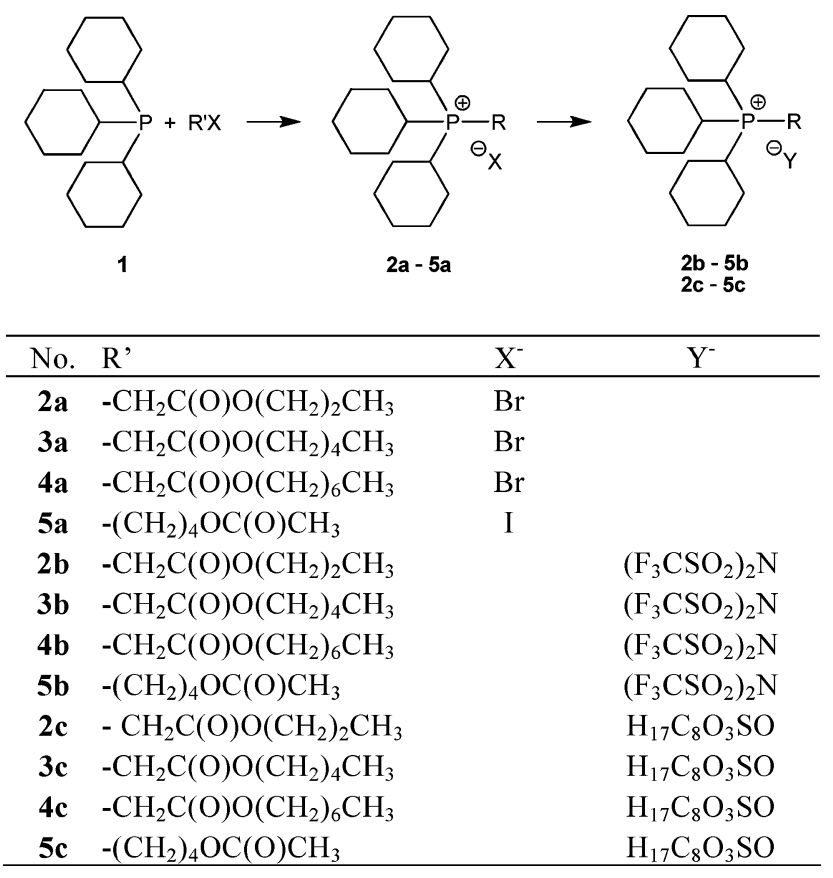

Scheme 1 Synthesis of tricyclohexyl PILs.

The biodegradability of the tricyclohexyl PILs were subsequently assessed by the $\mathrm{CO}_{2}$ headspace test. Both initial concentrations of $20 \mathrm{mg} \mathrm{C} / \mathrm{L}$ and $10 \mathrm{mg} \mathrm{C} / \mathrm{L}$ were examined and the results were compared to the reference substance sodium $n$-dodecyl sulfate (SDS) (Table 1/Fig. 1).

Phosphonium ionic liquids 2a, 3a, $\mathbf{4 a}, \mathbf{2 b}, \mathbf{3 b}$ and $\mathbf{4 b}$ underwent $<10 \%$ biodegradation after the standard 28 day incubation period. No significant differences were found as a function of the length of the alkyl side chain (2a, 3a, and $\mathbf{4 a} ; \mathbf{2} \mathbf{b}, \mathbf{3 b}$ and 4b) nor between ionic liquids containing bromide as counterion 
Table 1 Percentage of biodegradation of tricyclohexyl PILs after 28 days as determined by the $\mathrm{CO}_{2}$ headspace test

\begin{tabular}{llc}
\hline Compound & Biodegradation $^{a}(\%)$ & Biodegradation $^{b}(\%)$ \\
\hline $\mathbf{2 a}$ & 4 & 7 \\
$\mathbf{3 a}$ & 3 & 9 \\
$\mathbf{4 a}$ & 2 & 9 \\
$\mathbf{5 a}$ & 9 & - \\
$\mathbf{2 b}$ & 7 & - \\
$\mathbf{3 b}$ & 2 & - \\
$\mathbf{4 b}$ & 3 & 9 \\
$\mathbf{5 b}$ & 9 & 23 \\
$\mathbf{2 c}$ & 18 & - \\
$\mathbf{3 c}$ & 22 & 27 \\
$\mathbf{4 c}$ & 21 & 25 \\
$\mathbf{5 c}$ & 22 &
\end{tabular}

${ }^{a} \mathrm{IL}$ initial concentration $=20 \mathrm{mg} \mathrm{C} / \mathrm{L} .{ }^{b} \mathrm{IL}$ initial concentration $=$ $10 \mathrm{mg} \mathrm{C} / \mathrm{L}$.
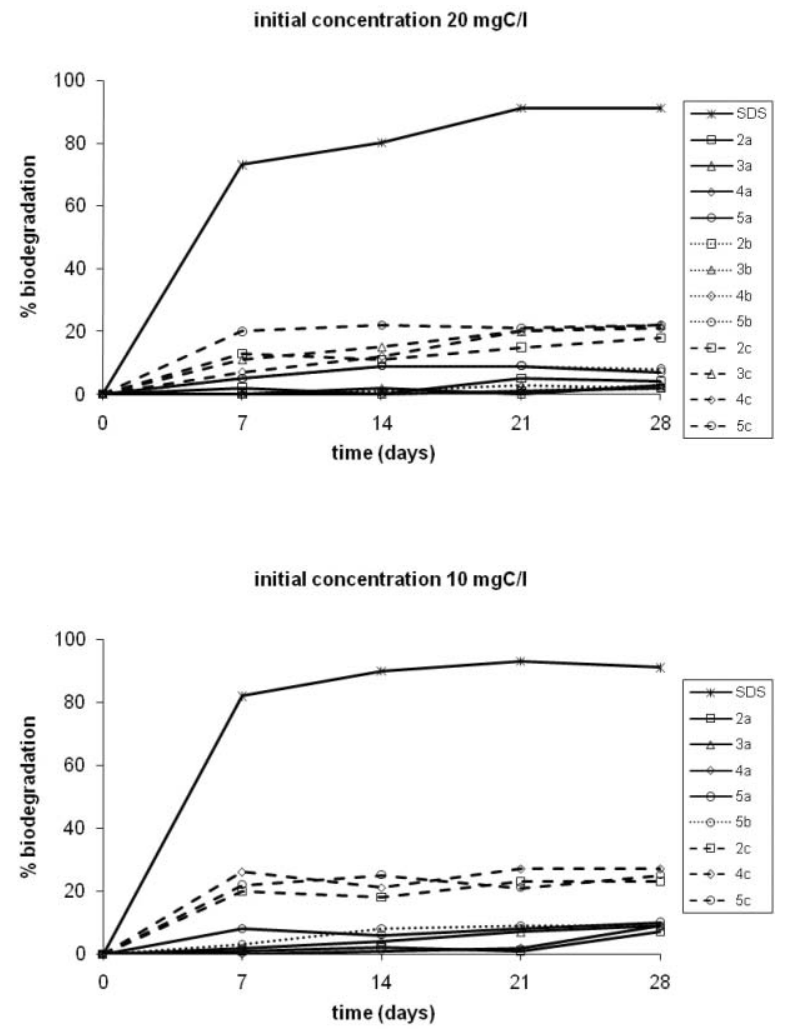

Fig. 1 Biodegradation of tricyclohexylphosphine based based quaternary salts with an ester group on the side chain in the $\mathrm{CO}_{2}$ headspace test: initial concentration of $20 \mathrm{mg} \mathrm{C} / \mathrm{L}$ (top) and initial concentration of $10 \mathrm{mg} \mathrm{C} / \mathrm{L}$ (bottom).

(water-soluble compounds $\mathbf{2 a}, \mathbf{3 a}$ and $\mathbf{4 a}$ ) and those containing triflimide as counterion (water immiscible compounds $\mathbf{2 b}, \mathbf{3 b}$ and $\mathbf{4 b}$ ).

In our earlier work, the incorporation of an ester bond susceptible to hydrolysis in the side chain resulted in a significant enhancement of biodegradability for both imidazolium and pyridinium based ionic liquids. Regarding the structure of phosphonium ionic liquids containing an ester group in the chain side, it seems reasonable that the biodegradation of these molecules may be initiated by a simple hydrolytic cleavage of the ester bond leading to the separation of the tricyclohexylphosphonium fragment and the corresponding primary alcohol or fatty acid that can be readily metabolized via the pathway of fatty acid $\beta$-oxidation. However, compounds 2a, 3a, 4a, 2b, 3b and $\mathbf{4 b}$ show lower biodegradation values than those calculated from the mineralization of the primary alcohol released in the ester bond hydrolysis. On the contrary, in the case of compounds $\mathbf{5 a}$ and $\mathbf{5 b}$ the percentage of biodegradation corresponds quite closely to the proportion of organic carbon content of the acetic acid released from the hydrolysis of the ester bond leaving the phosphonium moiety intact. For the former tricyclohexylphosphine based ionic liquids with ester side derived from $\mathrm{C} 3$ to $\mathrm{C} 7$ alcohol), the hydrolysis rate of the ester linkage by esterases could be limited by the steric hindrance of the cyclohexyl substituents on the phosphorous atom.

The biodegradation data should be interpreted with caution taking into account the features both of the biodegradation test applied as well as of the chemicals studied. Screening methods have been used in many studies on the biodegradability of quaternary ammonium compounds, namely surfactants such as alkyltrimethyl ammonium salts and benzylalkyldimethylammonium salts. ${ }^{34}$ Many quaternary ammonium salts are potential biocides and could inhibit growth of microorganisms capable of degrading quaternary ammonium salts. Since phosphonium ionic liquids are isostructural, similar results would be expected. Thus, the potential toxicity of the phosphonium ionic liquids might also have a negative impact on their biodegradation. These effects have been already described for the ionic liquid trihexyltetradecylphosphonium chloride by Wells and Coombe. ${ }^{32}$ To evaluate the toxicity of the tricyclohexylphosphine based ILs to the microorganisms responsible for aerobic biodegradation, solutions containing a mixture of the compound and a reference substance (SDS) were tested (Table 2). Biodegradation percentages for the mixtures of phosphonium ionic liquids and SDS were calculated based on the theoretical IC yield anticipated from only the reference substance. For all the tricyclohexylphosphine based ionic liquids tested, a certain degree of inhibition of the inoculum activity was found. However, the inhibition percentages were lower than the limit commonly accepted to consider inhibitory effects $(<25 \%)$. Furthermore, the phosphonium ionic liquids $\mathbf{2 a}, \mathbf{3 a}, \mathbf{4 a}, \mathbf{5 a}$ and $\mathbf{5 b}$ were tested at a lower initial concentration, $10 \mathrm{mg} \mathrm{C} / \mathrm{L}$, (Table 1). The biodegradation percentages found were similar or slightly higher than those obtained at $20 \mathrm{mg} \mathrm{C} / \mathrm{L}$. This result supports the conclusion that these ionic liquids are slightly toxic to the inoculum used in the biodegradation tests. Although these compounds are slightly inhibitory at the concentration applied in the test, toxicity seems to play a minor role in their low biodegradation and the non-amenability of tricyclohexylphosphine based cations to

Table 2 Inhibition of sodium dodecylsulfate biodegradation by tricylclohexyl PILs

\begin{tabular}{lll}
\hline Compound & Concentration $(\mathrm{mg} \mathrm{C} / \mathrm{L})$ & Inhibition $(\%)$ \\
\hline SDS + 2a & $20+20$ & 12 \\
SDS + 3a & $20+20$ & 19 \\
SDS + 4a & $20+20$ & 20 \\
SDS + 5a & $20+20$ & 20 \\
SDS + 5b & $20+20$ & 8 \\
\hline
\end{tabular}


microbial attack under the conditions of the test would be the main contribution.

A significant biodegradability increase was obtained when octylsulfate was employed as counterion (phosphonium ionic liquids $\mathbf{2 c}, \mathbf{3 c}, \mathbf{4 c}$ and $\mathbf{5 c}$ ) which is obviously an effect induced by the introduction of an organic anion readily catabolised. These observations on the effect of octylsulfate on ultimate biodegradability of phosphonium ionic liquids are consistent with the earlier results reported for imidazolium ${ }^{17,19,20}$ and pyridinium $^{25}$ based ionic liquids.

Our second set of evaluated PILs contain the tri- $n$ hexylphosphine based cation with ester, allyl, ether and alcohol side chains. The synthesis of these compound is described in Scheme 2 (below).

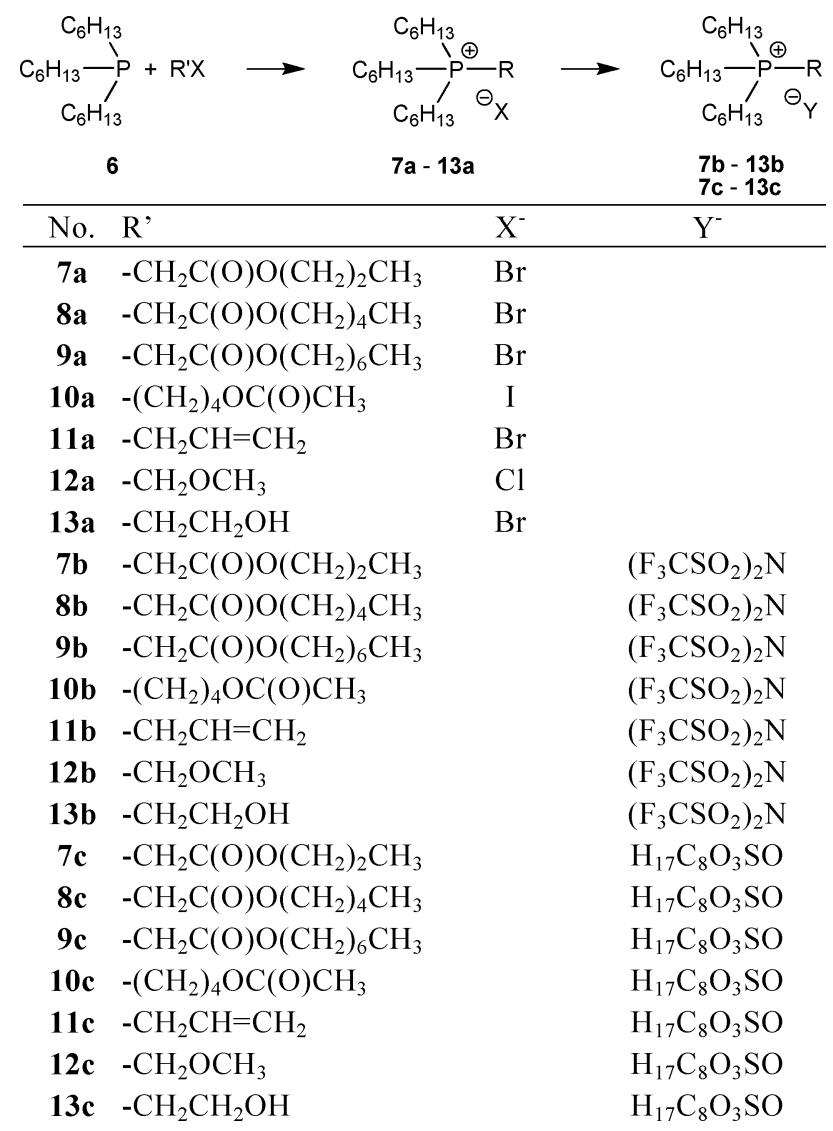

Scheme 2 Synthesis of tri- $n$-hexyl PILs.

This time the alkylations were performed at $50{ }^{\circ} \mathrm{C}$, since tri- $n$-hexylphosphine is a liquid at room temperature. PILs 7a-13a were purified by simply removing slight excess haloalkane under reduced pressure, so that no organic solvent is necessary in their formation. ILs 7a-13a were obtained in almost quantitative yields $(>95 \%)$ as room temperature liquids. The small impurities observable in the ${ }^{31} \mathrm{P}$ NMR spectra originate from tri-n-hexylphosphine. We decided however, in view of possible future large scale applications, not to purify this commercial starting material any further. The metathesis reactions to form triflimide salts $\mathbf{7 b}-\mathbf{1 3} \mathbf{b}$ and octylsulfate salts 7c-13c respectively, were carried out in a mixture of $\mathrm{MeOH}$ and water, as the halide salts 7a-13a have low solubility in pure water. The products were isolated in excellent yields $(>87 \%)$,
Table 3 Percentage of biodegradation of tri- $n$-hexyl PILs with ester side chains after 28 days as determined by the $\mathrm{CO}_{2}$ headspace test

\begin{tabular}{|c|c|c|c|}
\hline No. & Side Chain Functionality & Anion & Biodegradation $^{a}(\%)$ \\
\hline $7 a$ & Ester & $\mathrm{Br}^{-}$ & 12 \\
\hline $8 \mathbf{a}$ & Ester & $\mathrm{Br}^{-}$ & 4 \\
\hline $9 a$ & Ester & $\mathrm{Br}^{-}$ & 10 \\
\hline $10 a$ & Ester & $\mathrm{I}^{-}$ & 0 \\
\hline $11 \mathrm{a}$ & Allyl & $\mathrm{Br}^{-}$ & 8 \\
\hline $12 \mathbf{a}$ & Ether & $\mathrm{Cl}^{-}$ & 2 \\
\hline 13a & alcohol & $\mathrm{Br}^{-}$ & 0 \\
\hline $7 b$ & Ester & $\mathrm{Tf}_{2} \mathrm{~N}^{-}$ & 0 \\
\hline $8 \mathbf{b}$ & Ester & $\mathrm{Tf}_{2} \mathrm{~N}^{-}$ & 2 \\
\hline $9 \mathrm{~b}$ & Ester & $\mathrm{Tf}_{2} \mathrm{~N}^{-}$ & 0 \\
\hline $10 \mathrm{~b}$ & Ester & $\mathrm{Tf}_{2} \mathrm{~N}^{-}$ & 0 \\
\hline $11 b$ & Allyl & $\mathrm{Tf}_{2} \mathrm{~N}^{-}$ & 0 \\
\hline $12 \mathrm{~b}$ & Ether & $\mathrm{Tf}_{2} \mathrm{~N}^{-}$ & 0 \\
\hline 13b & alcohol & $\mathrm{Tf}_{2} \mathrm{~N}^{-}$ & 0 \\
\hline $7 c$ & Ester & $\mathrm{OctOSO}_{3}{ }^{-}$ & 15 \\
\hline $8 c$ & Ester & $\mathrm{OctOSO}_{3}^{-}$ & 20 \\
\hline $9 \mathrm{c}$ & Ester & $\mathrm{OctOSO}_{3}^{-}$ & 30 \\
\hline $10 \mathrm{c}$ & Ester & $\mathrm{OctOSO}_{3}^{-}$ & 5 \\
\hline $11 \mathrm{c}$ & Allyl & $\mathrm{OctOSO}_{3}^{-}$ & 18 \\
\hline $12 \mathrm{c}$ & Ether & $\mathrm{OctOSO}_{3}^{-}$ & 11 \\
\hline $13 \mathrm{c}$ & alcohol & $\mathrm{OctOSO}_{3}^{-}$ & 9 \\
\hline
\end{tabular}

tested with $\mathrm{AgNO}_{3}$ for halide residues and are all liquids at room temperature.

The biodegradability of the tri-n-hexyl PILs was again evaluated using the $\mathrm{CO}_{2}$ headspace test (ISO 14593, OECD 310) with SDS as standard (see Table 3 and Fig. 2). Since the series of previously evaluated tricyclohexylphosphine based
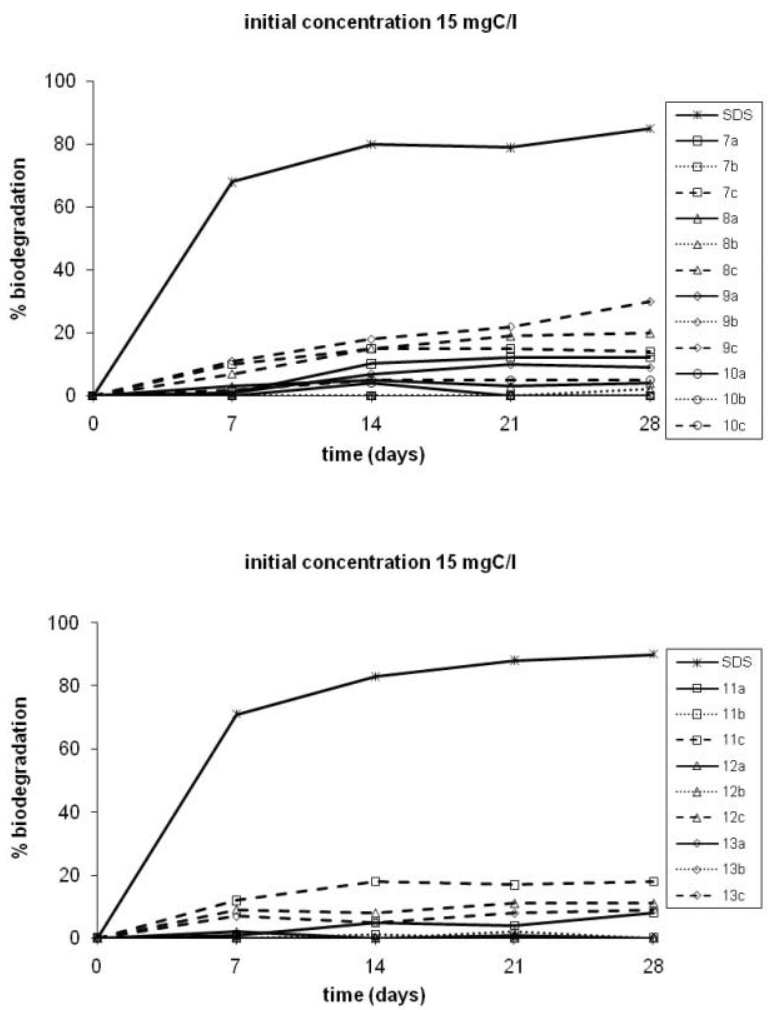

Fig. 2 Biodegradation of tri- $n$-hexylphosphonium based quaternary salts with ester (top) or allyl, ether or alcohol (bottom) side chains in the $\mathrm{CO}_{2}$ headspace test. 
Table 4 Inhibition of sodium dodecylsulfate biodegradation by tri-nhexyl PILs

\begin{tabular}{lll}
\hline Compound & Concentration $(\mathrm{mg} \mathrm{C} / \mathrm{L})$ & Inhibition $(\%)$ \\
\hline SDS + 7a & $20+15$ & 19 \\
SDS + 9a & $20+15$ & 18 \\
SDS + 10a & $20+15$ & 25 \\
SDS + 11a & $20+15$ & 28 \\
SDS + 12a & $20+15$ & 8 \\
SDS + 13a & $20+15$ & 4 \\
\hline
\end{tabular}

ionic liquids had shown some toxicity towards the inoculum at the concentration normally used in this biodegradation test $(20 \mathrm{mg} \mathrm{C} / \mathrm{L})$, the biodegradability assessment of tri- $n$ hexylphosphine based ionic liquids was carried out at a lower test substance concentration, $15 \mathrm{mg} \mathrm{C} / \mathrm{L}$, that did not reduce the precision of the test method.

All tri- $n$-hexyl PILs tested with halide or triflimide anions underwent biodegradation of $<12 \%$. No significant difference can be observed for different alkyl chain length (7a, 8a and 9a) and the triflimide anion $(\mathbf{7 b}, \mathbf{8 b}$, and $\mathbf{9 b}$ ) inhibited biodegradation even further. In comparison the tricyclohexyl ester $\mathbf{5 a}$ and $\mathbf{5 b}$, tri- $n$-hexyl esters 10a and $\mathbf{1 0 b}$ seem not to decay via ester hydrolysis, as the percentage of biodegradation does not correspond to the proportion of organic carbon content of the acetic acid released from the hydrolysis of the ester bond. Incorporation of allyl, ether or alcohol functionality (11a, 12a and 13a) does not alter the observed biodegradation significantly and again the triflimide anion $(\mathbf{1 1 b}, \mathbf{1 2 b}$, and 13b) seems to inhibit biodegradation even further. Only the organic octylsulfate anion enhances, as expected, the decay of the tri- $n$-hexyl PILs.

The toxicity of the tri- $n$-hexyl PILs to the microorganisms responsible for aerobic biodegradation were evaluated by testing solutions containing a mixture of the compound and SDS were tested (Table 4). All the tested compounds showed some degree of inhibition of the inoculum activity. For most of them, inhibition percentages lower than the limit commonly accepted to consider inhibitory effects $(<25 \%)$ were found (7a, 9a, 12a and 13a). The results lead us to the conclusion that these tri- $n$-hexyl PILs, like the tricyclohexyl PILs described above, are slightly toxic to the inoculum used in the biodegradation tests. However PILs 10a and 11a show inhibition levels of $25 \%$ and $28 \%$ respectively. Therefore in these cases toxicity may play a more significant role in their low biodegradation. The low susceptibility of tri- $n$-hexylphosphine based cations to microbial attack under the conditions of the test seems to be the main contribution to the low biodegradability, quite similar to the results obtained for tricyclohexyl PILs.

\section{Conclusions}

Based on our experience with imidazolium and pyridinium ILs, a suite of novel PILs was designed, synthesised and characterised in good to excellent yields. In the case of the tri- $n$-hexylphosphine based cations, the initial halide IL is obtainable without use of any organic solvent, making their synthesis attractive from an environmental point of view.

All of these PILs showed modest to poor levels of biodegradation in the $\mathrm{CO}_{2}$ headspace test. In fact all of the PILs with either halide or triflimide anions underwent low levels of biodegradation $(\leq 12 \%)$ in the 28 day test period. An increase in biodegradation was observed when an octylsulfate anion was employed, as expected. However, in all cases biodegradation was still $\leq 30 \%$, which is well short of the mark required for classification as 'readily biodegradable' ( $>60 \%)$. The incorporation of ester functionality into a side chain of the cation combined with the selection of the octyl sulfate anion has previously been shown to confer significantly higher levels of biodegradability in the both the dialkylimidazolium and pyridinium classes of IL. ${ }^{20,25}$ The failure of these modifications to improve biodegradation of the phosphonium ILs included in this study beyond 30\% after 28 days highlights their recalcitrant nature.

The presence of high concentrations of quaternary phosphonium salts produces from slight to moderate inhibition of the growth of microorganisms capable of degrading organic compounds. It might be therefore possible to find different conditions, under which PILs can undergo higher levels of natural decay.

\section{Experimental}

\section{Synthesis}

Tricyclohexylphosphine, tri- $n$-hexylphosphine, iodobutyl acetate, lithium triflimide, allyl bromide, methoxymethyl chloride, bromoethanol, $\mathrm{AgNO}_{3}$, and $\mathrm{MgSO}_{4}$ as well as all solvents were purchased from commercial suppliers (Sigma-Aldrich, TCI, Fluka) and used without further purification. Propyl bromoacetate, pentyl bromoacetate, heptyl bromoacetate ${ }^{17 \mathrm{~b}}$ and ammonium octylsulfate ${ }^{29}$ were prepared as described elsewhere. ${ }^{1} \mathrm{H}$ and proton de-coupled ${ }^{31} \mathrm{P}$ NMR spectra were acquired on a Bruker Avance DPX 300 spectrometer at 300 and $121 \mathrm{MHz}$ respectively, while proton de-coupled ${ }^{13} \mathrm{C} \mathrm{NMR}$ spectra were acquired on a Varian INOVA 600 spectrometer equipped with a cryo probe at $151 \mathrm{MHz}$. High-resolution electrospray ionisation (ESI) mass spectra were recorded on a Waters LCT Premier XE (TOF).

\section{General procedure for the synthesis of tricyclohexylphosphine based halide salts}

Tricyclohexylphosphine 1 (1.00 g, $3.57 \mathrm{mmol})$ was dried in a round bottom flask with side arm adaptor and septum over high vacuum. The flask was purged three times with $\mathrm{N}_{2}$ and subsequently immersed into an oil bath $\left(90^{\circ} \mathrm{C}\right)$. After the solid had melted, the appropriate haloalkane was added via syringe and the mixture was stirred at $90{ }^{\circ} \mathrm{C}$. The mixture was cooled to room temperature before the product was recrystallized from acetonitrile/diethyl ether and dried over night at $50^{\circ} \mathrm{C}$ over high vacuum.

\section{Tricyclohexyl(propoxycarbonylmethyl)phosphonium bromide} (2a)

The phosphine 1 and propyl bromoacetate $(678 \mathrm{mg}, 3.75 \mathrm{mmol})$ gave after 15 min stirring and recrystallization $1.27 \mathrm{~g}(78 \%)$ of the desired product as a clear white gel; $\delta_{\mathrm{H}}(300 \mathrm{MHz}$; DMSO $\left.d_{6}\right) 4.12(2 \mathrm{H}, \mathrm{t}, J$ 6.4), 3.87 ( $2 \mathrm{H}, \mathrm{d}, J 13.6), 2.67$ (3 H, q, $J$ 11.8), $1.92(6 \mathrm{H}$, br s), $1.80(6 \mathrm{H}$, br s), 1.6-1.61 (5 H, m), 1.50-1.24 $(15 \mathrm{H}, \mathrm{m}), 0.93(3 \mathrm{H}, \mathrm{t}, J 7.3 \mathrm{~Hz}) ; \delta_{\mathrm{C}}\left(150 \mathrm{MHz}\right.$; DMSO $\left.d_{6}\right)$ 
165.9, 67.6, 29.3 (d, $J$ 40), 25.9, 25.8, 24.8, 21.2 (d, $J$ 40), 21.2, $10.1 ; \delta_{\mathrm{P}}\left(121 \mathrm{MHz} ; \mathrm{DMSO} d_{6} ; 85 \% \mathrm{H}_{3} \mathrm{PO}_{4}\right) 35.3 ; \mathrm{m} / z(\mathrm{ESI},+\mathrm{ve})$ $381.2924\left[\left(\mathrm{M}-\mathrm{Br}^{-}\right)^{+}\right.$requires 381.2917].

\section{Tricyclohexyl(pentoxycarbonylmethyl)phosphonium bromide} (3a)

The phosphine 1 and pentyl bromoacetate $(820 \mathrm{mg}, 3.92 \mathrm{mmol}$ ) gave after $15 \mathrm{~min}$ stirring and recrystallization $1.32 \mathrm{~g}(76 \%)$ of the desired product as a clear white gel; $\delta_{\mathrm{H}}(300 \mathrm{MHz}$; DMSO $\left.d_{6}\right) 4.16(2 \mathrm{H}, \mathrm{t}, J$ 6.4), 3.88 (2 H, d, $J$ 13.6), 2.68 (3 H, q, $J$ 12.1), 1.92 (6 H, br s), 1.79 (6 H, br s), 1.70-1.61 (5 H, m), 1.50-1.24 (19 $\mathrm{H}, \mathrm{m}), 0.88(3 \mathrm{H}, \mathrm{t}, J 6.7) ; \delta_{\mathrm{C}}\left(150 \mathrm{MHz}\right.$; DMSO $\left.d_{6}\right) 165.9,66.0$, 29.3 (d, $J 40$ ), 27.4, 25.9, 25.8, 25.5, 24.8, 21.6, 21.1 (d, $J 42$ ), $13.7 ; \delta_{\mathrm{P}}\left(121 \mathrm{MHz} ; \mathrm{DMSO} d_{6} ; 85 \% \mathrm{H}_{3} \mathrm{PO}_{4}\right) 35.3 ; \mathrm{m} / z$ (ESI, +ve) 409.3237 [(M-Br- $)^{+}$requires 409.3230].

\section{Tricyclohexyl(heptoxycarbonylmethyl)phosphonium bromide} (4a)

The phosphine 1 and heptyl bromoacetate (930 mg, $3.92 \mathrm{mmol}$ ) gave after $15 \mathrm{~min}$ stirring and recrystallization $1.01 \mathrm{~g}(55 \%)$ of the desired product as a clear off white gel; $\delta_{\mathrm{H}}(300 \mathrm{MHz}$; DMSO $\left.d_{6}\right) 4.15$ (2 H, t, J 6.2), 3.86 (2 H, d, J 13.5), 2.67 (3 H, q, J 11.7), 1.92 (6 H, br s), 1.79 (6 H, br s), 1.70-1.60 (5 H, m), 1.50-1.26 $(23 \mathrm{H}, \mathrm{m}), 0.86\left(3 \mathrm{H}, \mathrm{t}, J\right.$ 6.7); $\delta_{\mathrm{C}}\left(150 \mathrm{MHz}\right.$; DMSO $\left.d_{6}\right) 165.5$, 66.6, 31.6, 29.9 (d, $J$ 40), 28.7, 28.3, 26.4, 26.3, 25.8, 25.4, 22.4, 21.7 (d, $J 44), 14.4 ; \delta_{\mathrm{P}}\left(121 \mathrm{MHz}\right.$; DMSO $\left.d_{6} ; 85 \% \mathrm{H}_{3} \mathrm{PO}_{4}\right) 35.3$; $\mathrm{m} / \mathrm{z}(\mathrm{ESI},+\mathrm{ve}) 437.3550\left[\left(\mathrm{M}-\mathrm{Br}^{-}\right)^{+}\right.$requires 437.3543].

\section{Tricyclohexyl(acetoxybutyl))phosphonium iodide (5a)}

The phosphine 1 and 4-iodobutyl acetate $(0.670 \mathrm{~mL}, 4.45 \mathrm{mmol})$ gave after $60 \mathrm{~min}$ stirring and recrystallization $1.71 \mathrm{~g}(92 \%)$ of the desired product as a light sensitive clear white gel; $\delta_{\mathrm{H}}(300 \mathrm{MHz}$; DMSO $\left.d_{6}\right) 4.07(2 \mathrm{H}, \mathrm{t}, J 6.2), 2.56$ (3 H, q, $J$ 11.6), 2.35-2.25 (2 $\mathrm{H}, \mathrm{m}), 2.00(3 \mathrm{H}, \mathrm{s}), 1.88$ (6 H, br s), 1.77 (8 H, br s), 1.72-1.66 (6 $\mathrm{H}, \mathrm{m}), 1.51-1.34(14 \mathrm{H}, \mathrm{m}) ; \delta_{\mathrm{C}}\left(150 \mathrm{MHz}\right.$; DMSO $\left.d_{6}\right) 170.2,62.4$, 29.0 (d, $J$ 15), 28.5 (d, $J$ 41), 26.0 (d, $J$ 2), 25.7 (d, $J 12), 24.8$, $20.6,18.0,13.6(\mathrm{~d}, J 44) ; \delta_{\mathrm{P}}\left(121 \mathrm{MHz}\right.$; DMSO $\left.d_{6} ; 85 \% \mathrm{H}_{3} \mathrm{PO}_{4}\right)$ $34.2 ; \mathrm{m} / \mathrm{z}(\mathrm{ESI},+\mathrm{ve}) 395.3072\left[\left(\mathrm{M}-\mathrm{I}^{-}\right)^{+}\right.$requires 395.3073].

\section{General procedure for the formation of tricyclohexyl phosphonium triflimide and octylsulfate salts}

An aqueous $(5 \mathrm{~mL})$ solution of lithium triflimide or ammonium octylsulfate was added to a solution $(10 \mathrm{~mL})$ of the phosphonium halide. The mixture was stirred at room temperature for $60 \mathrm{~min}$, $\mathrm{MeOH}$, if used, was removed under reduced pressure and the product was extracted into chloroform $(3 \times 10 \mathrm{~mL})$. The combined organic layers were washed with $10 \mathrm{~mL}$ portions of $\mathrm{H}_{2} \mathrm{O}$ until no precipitate was observed by the addition of $\mathrm{AgNO}_{3}$ to the aqueous layer. The organic layer was dried over $\mathrm{MgSO}_{4}$ and the solvent removed under reduced pressure, before the product was dried over night at $50{ }^{\circ} \mathrm{C}$ over high vacuum.

\section{Tricyclohexyl(propoxycarbonylmethyl)phosphonium triflimide} (2b)

Ionic liquid $2 \mathrm{a}$ (455 mg, $0.99 \mathrm{mmol}$ ) in $\mathrm{H}_{2} \mathrm{O}$ and lithium triflimide (311 mg, $1.08 \mathrm{mmol})$ gave $628 \mathrm{mg}(96 \%)$ of the desired product as off white wax; $\delta_{\mathrm{H}}\left(300 \mathrm{MHz}\right.$; DMSO $\left.d_{6}\right) 4.13(2 \mathrm{H}, \mathrm{t}, J 6.6), 3.83$ ( $2 \mathrm{H}, \mathrm{d}, J$ 13.6), 2.64 (3 H, q, $J$ 12.2), $1.91(6 \mathrm{H}, \mathrm{br} \mathrm{s}), 1.81(6 \mathrm{H}$, br s), 1.71-1.62 (5 H, m), 1.50-1.24 (15 H, m), 0.94 (3 H, t, $J 7.4)$; $\delta_{\mathrm{C}}\left(150 \mathrm{MHz} ; \mathrm{DMSO} d_{6}\right) 165.9,119.4(\mathrm{q}, J 322, \mathrm{C}-\mathrm{F}), 67.6,29.3$ $(\mathrm{d}, J 40), 25.9,25.8,24.8,21.2,21.1(\mathrm{~d}, J 43), 10.1 ; \delta_{\mathrm{P}}(121 \mathrm{MHz}$; DMSO $\left.d_{6} ; 85 \% \mathrm{H}_{3} \mathrm{PO}_{4}\right) 35.2 ; \mathrm{m} / z(\mathrm{ESI},+\mathrm{ve}) 381.2932\{[\mathrm{M}-$ $\left.\left(\mathrm{CH}_{3} \mathrm{SO}_{2}\right)_{2} \mathrm{~N}^{-}\right]^{+}$requires 381.2917\}; $\mathrm{m} / \mathrm{z}$ (ESI, -ve) 279.9169 $\left[\left(\mathrm{CH}_{3} \mathrm{SO}_{2}\right)_{2} \mathrm{~N}\right]^{-}$requires 279.9178 .

Tricyclohexyl(propoxycarbonylmethyl)phosphonium octylsulfate (2c)

Ionic liquid 2a (455 mg, $0.99 \mathrm{mmol}$ ) in $\mathrm{H}_{2} \mathrm{O}$ and ammonium octylsulfate $(224 \mathrm{mg}, 0.99 \mathrm{mmol})$ gave $524 \mathrm{mg}(90 \%)$ of the desired product as light yellow liquid; $\delta_{\mathrm{H}}\left(300 \mathrm{MHz}\right.$; DMSO $\left.d_{6}\right)$ 4.12 (2 H, t, $J$ 5.9), 3.83 ( $2 \mathrm{H}, \mathrm{d}, J 13.7), 3.66$ (2 H, t, $J 6.6), 2.64$ (3 H, q, $J$ 12.4), $1.91(6 \mathrm{H}$, br s), $1.80(6 \mathrm{H}$, br s), 1.70-1.62 (5 H, m), 1.49-1.25 (27 H, m), 0.94 (3 H, t, J 7.3), 0.86 (3 H, t, $J$ $5.7) ; \delta_{\mathrm{C}}\left(150 \mathrm{MHz}\right.$; DMSO $\left.d_{6}\right) 165.9,67.6,65.3,31.2,29.3(\mathrm{~d}, J$ 40), 29.0, 28.7, 28.6, 25.9, 25.8, 25.4, 24.8, 22.0, 21.2, 21.1 (d, $J$ $38), 13.8,10.1 ; \delta_{\mathrm{P}}\left(121 \mathrm{MHz}\right.$; DMSO $\left.d_{6} ; 85 \% \mathrm{H}_{3} \mathrm{PO}_{4}\right) 35.3 ; \mathrm{m} / z$ (ESI, +ve) $381.2931\left[\mathrm{M}-\left(\mathrm{C}_{8} \mathrm{H}_{17} \mathrm{OSO}_{3}^{-}\right)^{+}\right.$requires 381.2917].

Tricyclohexyl(pentoxycarbonylmethyl)phosphonium triflimide (3b)

Ionic liquid 3a (339 mg, $0.69 \mathrm{mmol}$ ) in $\mathrm{H}_{2} \mathrm{O}$ and lithium triflimide (219 $\mathrm{mg}, 0.76 \mathrm{mmol}$ ) gave $435 \mathrm{mg}(91 \%)$ of the desired product as light yellow liquid; $\delta_{\mathrm{H}}\left(300 \mathrm{MHz}\right.$; DMSO $\left.d_{6}\right) 4.16(2 \mathrm{H}, \mathrm{t}, J$ 6.5), 3.83 ( $2 \mathrm{H}, \mathrm{d}, J$ 13.6), 2.64 (3 H, q, $J 12.3$ ), 1.92 (6 H, br s), 1.81 (6 H, br s), 1.71-1.61 (5 H, m), 1.50-1.24 (19 H, m), 0.89 $(3 \mathrm{H}, \mathrm{t}, J 7.0) ; \delta_{\mathrm{C}}\left(150 \mathrm{MHz}\right.$; DMSO $\left.d_{6}\right) 165.9,119.4(\mathrm{q}, J 322$, C-F), 66.1, 29.3 (d, $J$ 40), 27.5, 25.9, 25.8, 25.5, 24.8, 21.6, 21.1 (d, $J 44), 13.7 ; \delta_{\mathrm{P}}\left(121 \mathrm{MHz}\right.$; DMSO $\left.d_{6} ; 85 \% \mathrm{H}_{3} \mathrm{PO}_{4}\right) 35.2 ; \mathrm{m} / z$ (ESI, +ve) $409.3223\left\{\left[\mathrm{M}-\left(\mathrm{CH}_{3} \mathrm{SO}_{2}\right)_{2} \mathrm{~N}^{-}\right]^{+}\right.$requires 409.3230$\}$; $\mathrm{m} / \mathrm{z}(\mathrm{ESI},-\mathrm{ve}) 279.9181\left[\left(\mathrm{CH}_{3} \mathrm{SO}_{2}\right)_{2} \mathrm{~N}\right]^{-}$requires 279.9178.

\section{Tricyclohexyl(pentoxycarbonylmethyl)phosphonium octylsulfate} (3c)

Ionic liquid 3a (339 mg, $0.69 \mathrm{mmol}$ ) in $\mathrm{H}_{2} \mathrm{O}$ and ammonium octylsulfate (157 mg, $0.69 \mathrm{mmol})$ gave $403 \mathrm{mg}(94 \%)$ of the desired product as light yellow liquid. $\delta_{\mathrm{H}}\left(300 \mathrm{MHz}\right.$; DMSO $\left.d_{6}\right)$ $4.16(2 \mathrm{H}, \mathrm{t}, J 6.5), 3.83$ (2 H, d, $J$ 13.6), 3.67 (2 H, t, $J 6.7), 2.65$ (3 H, q, $J$ 12.1), 1.92 (6 H, br s), 1.80 (6 H, br s), 1.71-1.61 (5 $\mathrm{H}, \mathrm{m}), 1.50-1.25(31 \mathrm{H}, \mathrm{m}), 0.91-0.84(6 \mathrm{H}, \mathrm{m}) ; \delta_{\mathrm{C}}(150 \mathrm{MHz}$; DMSO $\left.d_{6}\right) 165.9,66.1,65.3,31.2,29.3(\mathrm{~d}, J 40), 29.0,28.7,28.6$, 27.5, 25.9, 25.8, 25.7, 25.5, 24.8, 22.0, 21.6, 21.1 (d, $J$ 44), 13.8, 13.7; (121 MHz; DMSO $\left.d_{6} ; 85 \% \mathrm{H}_{3} \mathrm{PO}_{4}\right) 35.3 ; \mathrm{m} / z$ (ESI, +ve) $409.3189\left[\mathrm{M}-\left(\mathrm{C}_{8} \mathrm{H}_{17} \mathrm{OSO}_{3}^{-}\right)^{+}\right.$requires 409.3230]; $\mathrm{m} / \mathrm{z}$ (ESI, -ve) $209.0855\left(\mathrm{C}_{8} \mathrm{H}_{17} \mathrm{OSO}_{3}\right)^{-}$requires 209.0853 .

\section{Tricyclohexyl(heptoxycarbonylmethyl)phosphonium triflimide} (4b)

Ionic liquid 4a (296 mg, $0.57 \mathrm{mmol}) \mathrm{H}_{2} \mathrm{O}$ and lithium triflimide (191 mg, $0.67 \mathrm{mmol})$ gave $383 \mathrm{mg}(93 \%)$ of the desired product as light yellow liquid; $\delta_{\mathrm{H}}\left(300 \mathrm{MHz}\right.$; DMSO $\left.d_{6}\right) 4.16(2 \mathrm{H}, \mathrm{t}, J 6.4)$, 3.82 ( 2 H, d, $J$ 13.6, 2.64 (3 H, q, $J$ 12.2), 1.91 (6 H, br s), 1.81 (6 H, br s), 1.71-1.61 (5 H, m), 1.50-1.27 (23, H, m), 0.87 (3 H, t, $J$ $6.8) ; \delta_{\mathrm{C}}\left(150 \mathrm{MHz}\right.$; DMSO $\left.d_{6}\right) 165.9,119.4(\mathrm{q}, J 322, \mathrm{C}-\mathrm{F}), 66.1$, 
31.1, $29.3(\mathrm{~d}, J$ 40), 28.2, 27.8, 25.9, 25.8, 25.3, 24.8, 21.9, 21.1 $(\mathrm{d}, J 44), 13.8 ; \delta_{\mathrm{P}}\left(121 \mathrm{MHz} ; \mathrm{DMSO} d_{6} ; 85 \% \mathrm{H}_{3} \mathrm{PO}_{4}\right) 35.1 ; \mathrm{m} / z$ (ESI, +ve) $437.3542\left\{\left[\mathrm{M}-\left(\mathrm{CH}_{3} \mathrm{SO}_{2}\right)_{2} \mathrm{~N}^{-}\right]^{+}\right.$requires 437.3543$\}$; $\mathrm{m} / z(\mathrm{ESI},-\mathrm{ve}) 279.9174\left[\left(\mathrm{CH}_{3} \mathrm{SO}_{2}\right)_{2} \mathrm{~N}\right]^{-}$requires 279.9178.

Tricyclohexyl(heptoxycarbonylmethyl)phosphonium octylsulfate (4c)

Ionic liquid 4a (296 mg, $0.57 \mathrm{mmol}$ ) in $\mathrm{H}_{2} \mathrm{O}$ and ammonium octylsulfate $(130 \mathrm{mg}, 0.57 \mathrm{mmol})$ gave $348 \mathrm{mg}(94 \%)$ of the desired product as light yellow liquid; $\delta_{\mathrm{H}}\left(300 \mathrm{MHz}\right.$; DMSO $\left.d_{6}\right)$ 4.16 (2 H, t, $J$ 6.4), 3.83 ( 2 H, d, $J$ 13.6), 3.67 (2 H, t, $J$ 6.6), 2.65 (3 H, q, $J$ 12.2), 1.92 (6 H, br s), 1.80 (6 H, br s), 1.72-1.60 (5 $\mathrm{H}, \mathrm{m}), 1.50-1.25(35 \mathrm{H}, \mathrm{m}), 0.88-0.84(6 \mathrm{H}, \mathrm{m}) ; \delta_{\mathrm{C}}(150 \mathrm{MHz}$; DMSO $\left.d_{6}\right) 165.9,66.1,65.3,31.2,31.1,29.3(\mathrm{~d}, J 40), 29.0,28.7$, 28.6, 28.2, 27.8, 25.9, 25.8, 25.5, 25.3, 24.8, 22.0, 21.9, 21.1 (d, $J$ 44), 13.8, 13.8; $\delta_{\mathrm{P}}\left(121 \mathrm{MHz}\right.$; DMSO $\left.d_{6} ; 85 \% \mathrm{H}_{3} \mathrm{PO}_{4}\right) 35.3 ; \mathrm{m} / z$ (ESI, +ve) $437.3529\left[\mathrm{M}-\left(\mathrm{C}_{8} \mathrm{H}_{17} \mathrm{OSO}_{3}{ }^{-}\right)^{+}\right.$requires 437.3543]; $\mathrm{m} / \mathrm{z}$ (ESI, -ve) $209.0848\left(\mathrm{C}_{8} \mathrm{H}_{17} \mathrm{OSO}_{3}\right)^{-}$requires 209.0853.

\section{Tricyclohexyl(acetoxybutyl))phosphonium triflimide (5b)}

Ionic liquid 5a $(620 \mathrm{mg}, 1.19 \mathrm{mmol})$ in $\mathrm{MeOH}$ and lithium triflimide (375 mg, $1.31 \mathrm{mmol}$ ) gave $715 \mathrm{mg}(89 \%)$ of the desired product as clear liquid; $\delta_{\mathrm{H}}\left(300 \mathrm{MHz}\right.$; DMSO $\left.d_{6}\right) 4.08(2 \mathrm{H}$, $\mathrm{t}, J$ 6.2), 2.52 (3 H, q, $J$ 11.8), 2.32-2.23 (2 H, m), 2.01 (3 $\mathrm{H}, \mathrm{s}), 1.90-1.63(20 \mathrm{H}, \mathrm{m}), 1.51-1.24(14 \mathrm{H}, \mathrm{m}) ; \delta_{\mathrm{C}}(150 \mathrm{MHz}$; DMSO $\left.d_{6}\right) 170.2,119.4(\mathrm{q}, J 322, \mathrm{C}-\mathrm{F}), 62.4,29.0(\mathrm{~d}, J 15)$, 28.5 (d, $J$ 41), 26.0 (d, $J$ 2), 25.8 (d, $J$ 12), 24.9, 20.5, 18.0, $13.6(\mathrm{~d}, J 44) ; \delta_{\mathrm{P}}\left(121 \mathrm{MHz}\right.$; DMSO $\left.d_{6} ; 85 \% \mathrm{H}_{3} \mathrm{PO}_{4}\right) 34.0 ; \mathrm{m} / z$ $(\mathrm{ESI},+\mathrm{ve}) 395.3080\left\{\left[\mathrm{M}-\left(\mathrm{CH}_{3} \mathrm{SO}_{2}\right)_{2} \mathrm{~N}^{-}\right]^{+}\right.$requires 395.3073$\}$; $\mathrm{m} / \mathrm{z}(\mathrm{ESI},-\mathrm{ve}) 279.9189\left[\left(\mathrm{CH}_{3} \mathrm{SO}_{2}\right)_{2} \mathrm{~N}\right]^{-}$requires 279.9178.

\section{Tricyclohexyl(acetoxybutyl))phosphonium octylsulfate (5c)}

Ionic liquid 5a (620 mg, $1.19 \mathrm{mmol})$ in $\mathrm{MeOH}$ and ammonium octylsulfate $(270 \mathrm{mg}, 1.19 \mathrm{mmol})$ gave $704 \mathrm{mg}(98 \%)$ of the desired product as light yellow liquid; $\delta_{\mathrm{H}}\left(300 \mathrm{MHz}\right.$; DMSO $\left.d_{6}\right)$ 4.08 (2 H, t, $J$ 6.2), 3.67 ( $2 \mathrm{H}, \mathrm{d}, J 6.6), 2.53$ (3 H, q, $J$ 11.6), 2.33-2.24 (2 H, m), $2.01(3 \mathrm{H}, \mathrm{s}), 1.91-1.63(20 \mathrm{H}, \mathrm{m}), 1.50$ $1.25(26 \mathrm{H}, \mathrm{m}), 0.86\left(3 \mathrm{H}, \mathrm{t}, J\right.$ 6.7); $\delta_{\mathrm{C}}\left(150 \mathrm{MHz}\right.$; DMSO $\left.d_{6}\right)$ $170.2,79.1,65.3,62.4,31.2,29.0$ (d, $J$ 12), 28.6, 28.4 (d, $J 41$ ), 25.9, 25.8 (d, $J$ 12), 25.4, 24.9, 22.0, 20.6, 18.0, 13.8, 13.6 (d, $J$ 44); $\delta_{\mathrm{P}}\left(121 \mathrm{MHz} ; \mathrm{DMSO} d_{6} ; 85 \% \mathrm{H}_{3} \mathrm{PO}_{4}\right) 34.0 ; \mathrm{m} / z$ (ESI, +ve) $395.3067\left[\mathrm{M}-\left(\mathrm{C}_{8} \mathrm{H}_{17} \mathrm{OSO}_{3}{ }^{-}\right)^{+}\right.$requires 395.3073]; $\mathrm{m} / z(\mathrm{ESI},-\mathrm{ve})$ 209.0860 $\left(\mathrm{C}_{8} \mathrm{H}_{17} \mathrm{OSO}_{3}\right)^{-}$requires 209.0853.

\section{General procedure for the synthesis of tri-n-hexyl phosphonium halides}

A round bottom flask with side arm adaptor and septum, which was dried over high vacuum and purged three times with $\mathrm{N}_{2}$, was charged with tri- $n$-hexylphosphine 6 ( $2 \mathrm{~mL}, 5.79 \mathrm{mmol})$. The flask was subsequently immersed into an oil bath $\left(50^{\circ} \mathrm{C}\right)$, the appropriate haloalkane was added via syringe and the mixture was stirred at $50{ }^{\circ} \mathrm{C}$, before the product was dried over night at $50{ }^{\circ} \mathrm{C}$ over high vacuum.

\section{Tri-n-hexyl(propoxycarbonylmethyl)phosphonium bromide (7a)}

The phosphine 6 and propyl bromoacetate $(1.15 \mathrm{~g}, 6.34 \mathrm{mmol})$ gave after $2 \mathrm{~h}$ stirring and drying $2.66 \mathrm{~g}(98 \%)$ of the desired product as a clear liquid; $\delta_{\mathrm{H}}\left(300 \mathrm{MHz}\right.$; DMSO $\left.d_{6}\right) 4.09(2 \mathrm{H}$, t, $J$ 6.6), 3.93 (2 H, d, $J$ 14.4), 2.41-2.31 (6 H, m), 1.68-1.45 (8 $\mathrm{H}, \mathrm{m}), 1.39-1.27(18 \mathrm{H}, \mathrm{m}), 0.93-0.84(12 \mathrm{H}, \mathrm{m}) ; \delta_{\mathrm{C}}(150 \mathrm{MHz}$; DMSO $\left.d_{6}\right) 165.4(\mathrm{~d}, J 4), 67.3,30.3,29.7(\mathrm{~d}, J 16), 25.6(\mathrm{~d}, J 48)$, 21.7, 21.2, 20.4 (d, $J 4), 18.7(\mathrm{~d}, J 47), 13.7,10.1 ; \delta_{\mathrm{P}}(121 \mathrm{MHz}$; DMSO $\left.d_{6} ; 85 \% \mathrm{H}_{3} \mathrm{PO}_{4}\right) 34.1 ; \mathrm{m} / z(\mathrm{ESI},+\mathrm{ve}) 387.3391\left[\left(\mathrm{M}-\mathrm{Br}^{-}\right)^{+}\right.$ requires 387.3386$]$.

\section{Tri-n-hexyl(pentoxycarbonylmethyl)phosphonium bromide (8a)}

The phosphine 6 and pentyl bromoacetate $(1.33 \mathrm{~g}, 6.36 \mathrm{mmol})$ gave after $2 \mathrm{~h}$ stirring and drying $2.85 \mathrm{~g}(99 \%)$ of the desired product as a clear liquid; $\delta_{\mathrm{H}}\left(300 \mathrm{MHz}\right.$; DMSO $\left.d_{6}\right) 4.13(2 \mathrm{H}, \mathrm{t}, J$ 6.5), 3.88 (2 H, d, J 14.4), 2.38-2.28 (6 H, m), 1.63-1.50 (8 H, m), $1.39-1.27(22 \mathrm{H}, \mathrm{m}), 0.89-0.86(12 \mathrm{H}, \mathrm{m}) ; \delta_{\mathrm{C}}(150 \mathrm{MHz}$; DMSO $\left.d_{6}\right) 165.4,65.8,30.3,29.6(\mathrm{~d}, J 16), 27.5,27.4,25.6(\mathrm{~d}, J 48)$, 21.8, 21.7, $20.4(\mathrm{~d}, J 4), 18.4(\mathrm{~d}, J 47), 13.7,13.7 ; \delta_{\mathrm{P}}(121 \mathrm{MHz}$; DMSO $\left.d_{6} ; 85 \% \mathrm{H}_{3} \mathrm{PO}_{4}\right) 34.2 ; \mathrm{m} / z(\mathrm{ESI},+\mathrm{ve}) 415.3711\left[\left(\mathrm{M}-\mathrm{Br}^{-}\right)^{+}\right.$ requires 415.3699$]$.

\section{Tri-n-hexyl(heptoxycarbonylmethyl)phosphonium bromide (9a)}

The phosphine 6 and heptyl bromoacetate (1.51 g, $6.37 \mathrm{mmol})$ gave after $2 \mathrm{~h}$ stirring and drying $3.02 \mathrm{~g}(99 \%)$ of the desired product as a yellow liquid; $\delta_{\mathrm{H}}\left(300 \mathrm{MHz}\right.$; DMSO $\left.d_{6}\right) 4.13(2 \mathrm{H}$, $\mathrm{t}, J$ 6.5), 3.92 (2 H, d, $J$ 14.4), 2.41-2.31 (6 H, m), 1.62-1.45 (8 $\mathrm{H}, \mathrm{m}), 1.39-1.25(26 \mathrm{H}, \mathrm{m}), 0.89-0.84(12 \mathrm{H}, \mathrm{m}) ; \delta_{\mathrm{C}}(150 \mathrm{MHz}$; DMSO $\left.d_{6}\right)$ 165.4, 65.8, 31.1, 30.3, 29.6 (d, $J$ 16), 28.2, 27.8, 25.6 (d, $J$ 48), 25.2, 21.9, 21.7, 20.4 (d, $J 4), 18.4$ (d, $J$ 47), 13.7, $13.7 ; \delta_{\mathrm{P}}\left(121 \mathrm{MHz} ; \mathrm{DMSO} d_{6} ; 85 \% \mathrm{H}_{3} \mathrm{PO}_{4}\right) 34.1 ; \mathrm{m} / z$ (ESI, +ve) $443.4006\left[\left(\mathrm{M}-\mathrm{Br}^{-}\right)^{+}\right.$requires 443.4012$]$.

\section{Tri-n-hexyl(acetoxybutyl))phosphonium iodide (10a)}

The phosphine 6 and 4-iodobutyl acetate $(0.96 \mathrm{ml}, 6.39 \mathrm{mmol})$ 4-iodobutyl acetate gave after $4 \mathrm{~h}$ stirring and drying $3.01 \mathrm{~g}$ $(98 \%)$ of the desired product as a clear light sensitive liquid; $\delta_{\mathrm{H}}\left(300 \mathrm{MHz}\right.$; DMSO $\left.d_{6}\right) 4.03(2 \mathrm{H}, \mathrm{t}, J 6.3), 2.35-2.20(8 \mathrm{H}$, m), 2.00 (3 H, s), 1.75-1.66 (2 H, m), 1.59-1.28 (26 H, m), 0.87 $(9 \mathrm{H}, \mathrm{t}, J 6.9) ; \delta_{\mathrm{C}}\left(150 \mathrm{MHz}\right.$; DMSO $\left.d_{6}\right) 170.0,62.6,30.2,29.5$ (d, $J 15), 28.7$ (d, $J 15), 21.6,20.5$ (d, $J 17), 20.4,17.6,17.317 .1$ $(\mathrm{d}, J 48), 13.6 ; \delta_{\mathrm{P}}\left(121 \mathrm{MHz} ; \mathrm{DMSO} d_{6} ; 85 \% \mathrm{H}_{3} \mathrm{PO}_{4}\right) 35.0 ; \mathrm{m} / z$ $(\mathrm{ESI},+\mathrm{ve}) 401.3544\left[\left(\mathrm{M}-\mathrm{I}^{-}\right)^{+}\right.$requires 401.3543].

\section{Tri-n-hexylallylphosphonium bromide (11a)}

The phosphine 6 and allyl bromide $(0.55 \mathrm{ml}, 6.36 \mathrm{mmol})$ gave after $5 \mathrm{~h}$ stirring and drying $2.27 \mathrm{~g}(96 \%)$ of the desired product as a clear liquid; $\delta_{\mathrm{H}}\left(300 \mathrm{MHz}\right.$; DMSO $\left.d_{6}\right) 5.92-5.74(1 \mathrm{H}, \mathrm{m})$, 5.48-5.40 (1 H, m), 5.35-5.31 (1 H, m), 3.32 (2 H, dd, $J 16.2$ and 7.5), 2.32-2.22 (6 H, m), 1.55-1.47 (6 H, m), 1.39-1.27 (18 H, $\mathrm{m}), 0.86(9 \mathrm{H}, \mathrm{t}, J 6.7) ; \delta_{\mathrm{C}}\left(150 \mathrm{MHz}\right.$; DMSO $\left.d_{6}\right) 125.6(\mathrm{~d}, J 9)$, 122.7 (d, $J$ 12), 30.3, 29.6 (d, $J$ 15), 23.5 (d, $J$ 47), 21.7, 20.4 (d, $J$ 4), $17.5(\mathrm{~d}, J 47), 13.7 ; \delta_{\mathrm{P}}\left(121 \mathrm{MHz}\right.$; DMSO $\left.d_{6} ; 85 \% \mathrm{H}_{3} \mathrm{PO}_{4}\right)$ 33.3; $\mathrm{m} / \mathrm{z}(\mathrm{ESI},+\mathrm{ve}) 327.3179\left[\left(\mathrm{M}-\mathrm{Br}^{-}\right)^{+}\right.$requires 327.3175]. 


\section{Tri-n-hexyl(methoxymethyl)phosphonium chloride (12a)}

The phosphine 6 and methoxymethyl chloride $(0.48 \mathrm{~mL}$, $6.32 \mathrm{mmol})$ gave after $5 \mathrm{~h}$ stirring and drying $2.10 \mathrm{~g}(99 \%)$ of the desired product as a clear liquid; $\delta_{\mathrm{H}}\left(300 \mathrm{MHz}\right.$; DMSO $\left.d_{6}\right) 4.54$ (2 H, d, J 5.4), 3.41 (3 H, s), 2.39-2.28 (6 H, m), $1.52-1.44$ (6 $\mathrm{H}, \mathrm{m}), 1.37-1.26(18 \mathrm{H}, \mathrm{m}), 0.85\left(9 \mathrm{H}, \mathrm{t}, J\right.$ 6.5); $\delta_{\mathrm{C}}(150 \mathrm{MHz}$; DMSO $\left.d_{6}\right) 61.8(\mathrm{~d}, J 63), 61.3(\mathrm{~d}, J 12), 30.3,29.7(\mathrm{~d}, J 15)$, 21.7, 20.5 (d, $J$ 4), 16.5 (d, $J$ 46), 13.7; $\delta_{\mathrm{P}}\left(121 \mathrm{MHz}\right.$; DMSO $d_{6}$; $\left.85 \% \mathrm{H}_{3} \mathrm{PO}_{4}\right) 33.0 ; \mathrm{m} / \mathrm{z}(\mathrm{ESI},+\mathrm{ve}) 331.3120\left[\left(\mathrm{M}-\mathrm{Cl}^{-}\right)^{+}\right.$requires 331.3124].

\section{Tri-n-hexyl(2-hydroxyethyl)phosphonium bromide (13a)}

The phosphine 6 and 2-bromoethanol $(0.45 \mathrm{~mL}, 6.35 \mathrm{mmol})$ gave after $5 \mathrm{~h}$ stirring and drying $2.34 \mathrm{~g}(98 \%)$ of the desired product as a clear liquid; $\delta_{\mathrm{H}}\left(300 \mathrm{MHz}\right.$; DMSO $\left.d_{6}\right) 3.80-3.43$ $(3 \mathrm{H}, \mathrm{m}), 2.47(2 \mathrm{H}, \mathrm{td}, J 12.4$ and 6.1$), 2.31-2.21(6 \mathrm{H}, \mathrm{m})$, 1.57-1.44 (6 H, m), 1.39-1.25 (8 H, m), 0.86 (9 H, t, $J$ 6.8); $\delta_{\mathrm{C}}\left(150 \mathrm{MHz}\right.$; DMSO $\left.d_{6}\right) 54.1(\mathrm{~d}, J 6), 30.3,29.6(\mathrm{~d}, J 15), 21.7$, $21.4,20.5$ (d, $J$ 4), 18.3 (d, $J 47), 13.7 ; \delta_{\mathrm{P}}\left(121 \mathrm{MHz}\right.$; DMSO $d_{6}$; $\left.85 \% \mathrm{H}_{3} \mathrm{PO}_{4}\right) 34.4 ; \mathrm{m} / \mathrm{z}(\mathrm{ESI},+\mathrm{ve}) 331.3127\left[\left(\mathrm{M}-\mathrm{Br}^{-}\right)^{+}\right.$requires 331.3124].

\section{General procedure for the formation of tri-n-hexyl phosphonium} triflimide and octylsulfate salts

An aqueous $(10 \mathrm{~mL})$ solution of lithium triflimide or ammonium octylsulfate was added to a solution $(20 \mathrm{~mL})$ of the phosphonium halide in $\mathrm{MeOH}$. The mixture was stirred at room temperature for $60 \mathrm{~min}, \mathrm{MeOH}$ was removed under reduced pressure and the product was extracted into chloroform $(3 \times 20 \mathrm{~mL})$. The combined organic layers were washed with $20 \mathrm{~mL}$ portions of $\mathrm{H}_{2} \mathrm{O}$ until no precipitate was observed by the addition of $\mathrm{AgNO}_{3}$ to the aqueous layer. The organic layer was dried over $\mathrm{MgSO}_{4}$ and the solvent removed under reduced pressure, before the product was dried over night at $50{ }^{\circ} \mathrm{C}$ over high vacuum.

\section{Tri-n-hexyl(propoxycarbonylmethyl)phosphonium triflimide (7b)}

Ionic liquid $7 \mathbf{a}(1.10 \mathrm{~g}, 2.35 \mathrm{mmol})$ and lithium triflimide $(0.74 \mathrm{~g}$, $2.58 \mathrm{mmol})$ gave $1.46 \mathrm{~g}(93 \%)$ of the desired product as an off white liquid; $\delta_{\mathrm{H}}\left(300 \mathrm{MHz}\right.$; DMSO $\left.d_{6}\right) 4.11(2 \mathrm{H}, \mathrm{t}, J$ 6.6), $3.79(2$ $\mathrm{H}, \mathrm{d}, J$ 14.4), 2.33-2.23 (6 H, m), 1.68-1.26 (6 H, m), 0.94-0.86 $(12 \mathrm{H}, \mathrm{m}) ; \delta_{\mathrm{C}}\left(150 \mathrm{MHz}\right.$; DMSO $\left.d_{6}\right) 165.3(\mathrm{~d}, J 4), 119.4(\mathrm{q}$, $J$ 321, C-F), 67.4, 30.3, 29.6 (d, $J 16), 25.4$ (d, $J$ 49), 21.6, 21.1, $20.4(\mathrm{~d}, J 4), 18.3(\mathrm{~d}, J 47), 13.6,10.0 ; \delta_{\mathrm{P}}(121 \mathrm{MHz}$ DMSO $\left.d_{6} ; 85 \% \mathrm{H}_{3} \mathrm{PO}_{4}\right) 34.2 ; \mathrm{m} / z$ (ESI, +ve) $387.3383\{[\mathrm{M}-$ $\left.\left(\mathrm{CH}_{3} \mathrm{SO}_{2}\right)_{2} \mathrm{~N}^{-}\right]^{+}$requires 387.3386$\} ; \mathrm{m} / z$ (ESI, -ve) 279.9171 $\left[\left(\mathrm{CH}_{3} \mathrm{SO}_{2}\right)_{2} \mathrm{~N}\right]^{-}$requires 279.9178 .

\section{Tri-n-hexyl(propoxycarbonylmethyl)phosphonium octylsulfate (7c)}

Ionic liquid 7a (1.10 g, $2.35 \mathrm{mmol})$ and ammonium octylsulfate (0.54 g, $2.38 \mathrm{mmol})$ gave $1.30 \mathrm{~g}(93 \%)$ of the desired product as an off white liquid; $\delta_{\mathrm{H}}\left(300 \mathrm{MHz}\right.$; DMSO $\left.d_{6}\right) 4.10(2 \mathrm{H}, \mathrm{t}$, $J$ 6.6), 3.82 (2 H, d, $J$ 14.4), 3.68 (2 H, t, $J$ 6.6), 2.36-2.26 $(6 \mathrm{H}, \mathrm{m}), 1.67-1.48(10 \mathrm{H}, \mathrm{m}), 1.40-1.25(28 \mathrm{H}, \mathrm{m}), 0.94$ $0.84(15 \mathrm{H}, \mathrm{m}) ; \delta_{\mathrm{C}}\left(150 \mathrm{MHz}\right.$; DMSO $\left.d_{6}\right) 165.4(\mathrm{~d}, J 4), 67.3$, $65.3,31.2,30.3,29.6$ (d, $J 16), 29.0,28.7,28.6,25.4,25.3$ (d,
$J$ 48), 22.0, 21.7, 21.2, 20.4 (d, $J$ 4), 18.2 (d, $J$ 47), 13.7, 13.7, $10.0 ; \delta_{\mathrm{P}}\left(121 \mathrm{MHz} ; \mathrm{DMSO} d_{6} ; 85 \% \mathrm{H}_{3} \mathrm{PO}_{4}\right) 34.2 ; \mathrm{m} / z$ (ESI, +ve) $387.3382\left[\mathrm{M}-\left(\mathrm{C}_{8} \mathrm{H}_{17} \mathrm{OSO}_{3}{ }^{-}\right)^{+}\right.$requires 387.3386]; $\mathrm{m} / \mathrm{z}$ (ESI, -ve) $209.0862\left(\mathrm{C}_{8} \mathrm{H}_{17} \mathrm{OSO}_{3}\right)^{-}$requires 209.0853 .

\section{Tri-n-hexyl(pentoxycarbonylmethyl)phosphonium triflimide (8b)}

Ionic liquid 8a (1.19 g, $2.40 \mathrm{mmol})$ and lithium triflimide $(0.76 \mathrm{~g}$, $2.65 \mathrm{mmol})$ gave $1.59 \mathrm{~g}(95 \%)$ of the desired product as a light yellow liquid; $\delta_{\mathrm{H}}\left(300 \mathrm{MHz}\right.$; DMSO $\left.d_{6}\right) 4.14(2 \mathrm{H}, \mathrm{t}, J 6.5), 3.79$ (2 H, d, J 14.4), 2.33-2.23 (6 H, m), 1.62-1.29 (30 H, m), 0.90$0.86(12 \mathrm{H}, \mathrm{m}) ; \delta_{\mathrm{C}}\left(150 \mathrm{MHz}\right.$; DMSO $\left.d_{6}\right) 165.3(\mathrm{~d}, J 4), 119.4(\mathrm{q}$, $J$ 322, C-F), 65.9, 30.3, 29.6 (d, $J$ 16), 27.5, 27.4, 25.4 (d, $J$ 48), 21.8, 21.7, $20.4(\mathrm{~d}, J 4), 18.3(\mathrm{~d}, J 47), 13.6,13.6 ; \delta_{\mathrm{P}}(121 \mathrm{MHz}$; DMSO $\left.d_{6} ; 85 \% \mathrm{H}_{3} \mathrm{PO}_{4}\right) 34.2 ; \mathrm{m} / z$ (ESI, +ve) $415.3704\{[\mathrm{M}-$ $\left.\left(\mathrm{CH}_{3} \mathrm{SO}_{2}\right)_{2} \mathrm{~N}^{-}\right]^{+}$requires 415.3699$\} ; \mathrm{m} / z$ (ESI, -ve) 279.9170 $\left[\left(\mathrm{CH}_{3} \mathrm{SO}_{2}\right)_{2} \mathrm{~N}\right]^{-}$requires 279.9178 .

\section{Tri-n-hexyl(pentoxycarbonylmethyl)phosphonium octylsulfate (8c)}

Ionic liquid 8a (1.19 g, $2.40 \mathrm{mmol})$ and ammonium octylsulfate $(0.55 \mathrm{~g}, 2.42 \mathrm{mmol})$ gave $1.36 \mathrm{~g}(93 \%)$ of the desired product as a light yellow liquid; $\delta_{\mathrm{H}}\left(300 \mathrm{MHz}\right.$; DMSO $\left.d_{6}\right) 4.13(2 \mathrm{H}, \mathrm{t}, J$ 6.6), 3.81 (2 H, d, $J$ 14.4), 3.68 (2 H, t, $J$ 6.7), 2.36-2.26 (6 H, $\mathrm{m}), 1.64-1.46(10 \mathrm{H}, \mathrm{m}), 1.40-1.20(32 \mathrm{H}, \mathrm{m}), 0.90-0.85(15$ $\mathrm{H}, \mathrm{m}) ; \delta_{\mathrm{C}}\left(150 \mathrm{MHz}\right.$; DMSO $\left.d_{6}\right) 165.4(\mathrm{~d}, J 4), 65.8,65.3,31.2$, $30.3,29.6$ (d, $J$ 16), 29.0, 28.7, 28.6, 27.5, 27.4, 25.4, 25.3 (d, $J$ 48), 22.0, 21.7, 21.7, 20.4 (d, $J$ 4), 18.3 (d, $J$ 47), 13.7, 13.7, $13.6 ; \delta_{\mathrm{P}}\left(121 \mathrm{MHz} ; \mathrm{DMSO} d_{6} ; 85 \% \mathrm{H}_{3} \mathrm{PO}_{4}\right) 34.2 ; \mathrm{m} / z(\mathrm{ESI},+\mathrm{ve})$ $415.3690\left[\mathrm{M}-\left(\mathrm{C}_{8} \mathrm{H}_{17} \mathrm{OSO}_{3}{ }^{-}\right)^{+}\right.$requires 415.3699]; $\mathrm{m} / z$ (ESI, -ve) 209.0859 $\left(\mathrm{C}_{8} \mathrm{H}_{17} \mathrm{OSO}_{3}\right)^{-}$requires 209.0853.

\section{Tri-n-hexyl(heptoxycarbonylmethyl)phosphonium triflimide (9b)}

Ionic liquid 9a (1.24 g, $2.37 \mathrm{mmol})$ and lithium triflimide $(0.75 \mathrm{~g}$, $2.61 \mathrm{mmol})$ gave $1.60 \mathrm{~g}(93 \%)$ of the desired product as a light yellow liquid; $\delta_{\mathrm{H}}\left(300 \mathrm{MHz}\right.$; DMSO $\left.d_{6}\right) 4.14(2 \mathrm{H}, \mathrm{t}, J 6.5), 3.78$ (2 H, d, J 14.4), 2.33-2.23 (6 H, m), 1.64-1.48 (8 H, m), 1.41-1.28 $(26 \mathrm{H}, \mathrm{m}), 0.90-0.86(12 \mathrm{H}, \mathrm{m}) ; \delta_{\mathrm{C}}\left(150 \mathrm{MHz}\right.$; DMSO $\left.d_{6}\right) 165.3$ $(\mathrm{d}, J 4), 119.4(\mathrm{q}, J 322, \mathrm{C}-\mathrm{F}), 65.9,31.1,30.3,29.6(\mathrm{~d}, J 16)$, 28.3, 27.8, 25.4 (d, $J$ 48), 25.3, 22.0, 21.7, 20.4 (d, $J 4), 18.3$ (d, $J$ 47), $13.7,13.7 ; \delta_{\mathrm{P}}\left(121 \mathrm{MHz}\right.$; DMSO $\left.d_{6} ; 85 \% \mathrm{H}_{3} \mathrm{PO}_{4}\right) 34.2 ; \mathrm{m} / z$ (ESI, +ve) $443.4021\left\{\left[\mathrm{M}-\left(\mathrm{CH}_{3} \mathrm{SO}_{2}\right)_{2} \mathrm{~N}^{-}\right]^{+}\right.$requires 443.4012$\}$; $\mathrm{m} / \mathrm{z}(\mathrm{ESI},-\mathrm{ve}) 279.9172\left[\left(\mathrm{CH}_{3} \mathrm{SO}_{2}\right)_{2} \mathrm{~N}\right]^{-}$requires 279.9178.

\section{Tri-n-hexyl(heptoxycarbonylmethyl)phosphonium octylsulfate (9c)}

Ionic liquid 9a (1.24 g, $2.37 \mathrm{mmol})$ and ammonium octylsulfate $(0.54 \mathrm{~g}, 2.38 \mathrm{mmol})$ gave $1.39 \mathrm{~g}(90 \%)$ of the desired product as a light yellow liquid; $\delta_{\mathrm{H}}\left(300 \mathrm{MHz}\right.$; DMSO $\left.d_{6}\right) 4.13(2 \mathrm{H}, \mathrm{t}, J 6.5)$, $3.81(2 \mathrm{H}, \mathrm{d}, J 14.4), 3.68(2 \mathrm{H}, \mathrm{t}, J 6.7), 2.36-2.26(6 \mathrm{H}, \mathrm{m})$, 1.63-1.48 (10 H, m), 1.40-1.25 (36 H, m), 0.90-0.84 (15 H, m); $\delta_{\mathrm{C}}\left(150 \mathrm{MHz}\right.$; DMSO $\left.d_{6}\right) 165.4(\mathrm{~d}, J 4), 65.8,65.3,31.2,31.1$, $30.3,29.7$ (d, $J$ 16), 29.1, 28.7, 28.6, 28.3, 27.8, 25.4, 25.3, 25.3 (d, $J$ 47), 22.0, 22.0, 21.7, 20.4 (d, $J 4), 18.3$ (d, $J$ 47), 13.8, 13.7, $13.7 ; \delta_{\mathrm{P}}\left(121 \mathrm{MHz} ; \mathrm{DMSO} d_{6} ; 85 \% \mathrm{H}_{3} \mathrm{PO}_{4}\right) 34.2 ; \mathrm{m} / z$ (ESI, +ve) $443.4018\left[\mathrm{M}-\left(\mathrm{C}_{8} \mathrm{H}_{17} \mathrm{OSO}_{3}^{-}\right)^{+}\right.$requires 443.4012]; $\mathrm{m} / z$ (ESI, -ve) $209.0844\left(\mathrm{C}_{8} \mathrm{H}_{17} \mathrm{OSO}_{3}\right)^{-}$requires 209.0853 . 


\section{Tri-n-hexyl(acetoxybutyl))phosphonium triflimide (10b)}

Ionic liquid 10a (1.27 g, $2.40 \mathrm{mmol})$ and lithium triflimide $(0.76 \mathrm{~g}, 2.65 \mathrm{mmol})$ gave $1.51 \mathrm{~g}(92 \%)$ of the desired product as an off white liquid; $\delta_{\mathrm{H}}\left(300 \mathrm{MHz}\right.$; DMSO $\left.d_{6}\right) 4.05(2 \mathrm{H}, \mathrm{t}$, $J$ 6.3), $2.28-2.13$ (8 H, m), 2.00 (3 H, s), 1.76-1.67 (2 H, m), $1.61-1.29(26 \mathrm{H}, \mathrm{m}), 0.88(9 \mathrm{H}, \mathrm{t}, J 6.8) ; \delta_{\mathrm{C}}(150 \mathrm{MHz}$; DMSO $\left.d_{6}\right) 170.2,119.4(\mathrm{q}, J 321, \mathrm{C}-\mathrm{F}), 62.6,30.3,29.7(\mathrm{~d}, J 15)$, $28.8(\mathrm{~d}, J$ 16), 21.7, 20.5 (d, $J 16), 20.5,17.6,17.217 .0$ (d, $J$ 48), 13.7; $\delta_{\mathrm{P}}\left(121 \mathrm{MHz}\right.$; DMSO $\left.d_{6} ; 85 \% \mathrm{H}_{3} \mathrm{PO}_{4}\right) 35.0 ; \mathrm{m} / z$ (ESI, +ve) $401.3549\left\{\left[\mathrm{M}-\left(\mathrm{CH}_{3} \mathrm{SO}_{2}\right)_{2} \mathrm{~N}^{-}\right]^{+}\right.$requires 401.3543$\}$; $\mathrm{m} / \mathrm{z}(\mathrm{ESI},-\mathrm{ve}) 279.9183\left[\left(\mathrm{CH}_{3} \mathrm{SO}_{2}\right)_{2} \mathrm{~N}\right]^{-}$requires 279.9178.

\section{Tri-n-hexyl(acetoxybutyl))phosphonium octylsulfate (10c)}

Ionic liquid 10a $(1.27 \mathrm{~g}, 2.40 \mathrm{mmol})$ and ammonium octylsulfate $(0.55 \mathrm{~g}, 2.42 \mathrm{mmol})$ gave $1.40 \mathrm{~g}(95 \%)$ of the desired product as an off white liquid; $\delta_{\mathrm{H}}\left(300 \mathrm{MHz}\right.$; DMSO $\left.d_{6}\right) 4.04(2 \mathrm{H}, \mathrm{t}, J$ 6.3), 3.68 (2 H, t, $J$ 6.7), 2.31-2.16 (8 H, m), 2.00 (3 H, s), 1.75-1.66 (2 H, m), 1.59-1.25 (38 H, m), 0.90-0.84 (12 H, m); $\delta_{\mathrm{C}}\left(150 \mathrm{MHz}\right.$; DMSO $\left.d_{6}\right) 170.1,65.3,62.7,31.2,30.3,29.7(\mathrm{~d}$, $J$ 15), 29.0, 28.8 (d, $J$ 16), 28.7, 28.6, 25.5, 22.0, 21.8, 20.5 (d, $J$ 16), 20.5, 17.5, 17.217 .0 (d, $J$ 48), 13.8, 13.7; $\delta_{\mathrm{P}}(121 \mathrm{MHz}$; DMSO $\left.d_{6} ; 85 \% \mathrm{H}_{3} \mathrm{PO}_{4}\right) 35.0 ; \mathrm{m} / z$ (ESI, +ve) $401.3559[\mathrm{M}-$ $\left(\mathrm{C}_{8} \mathrm{H}_{17} \mathrm{OSO}_{3}^{-}\right)^{+}$requires 401.3543]; $\mathrm{m} / \mathrm{z}$ (ESI, -ve) 209.0847 $\left(\mathrm{C}_{8} \mathrm{H}_{17} \mathrm{OSO}_{3}\right)^{-}$requires 209.0853 .

\section{Tri-n-hexylallylphosphonium triflimide (11b)}

Ionic liquid 11a $(0.85 \mathrm{~g}, 2.09 \mathrm{mmol})$ and lithium triflimide $(0.66 \mathrm{~g}, 2.30 \mathrm{mmol})$ gave $1.11 \mathrm{~g}(88 \%)$ of the desired product as a clear liquid; $\delta_{\mathrm{H}}\left(300 \mathrm{MHz}\right.$; DMSO $\left.d_{6}\right) 5.87-5.72(1 \mathrm{H}, \mathrm{m})$, 5.46-5.34 (2 H, m), 3.18 (2 H, dd, $J 15.9$ and 7.4), 2.23-2.13 (6 H, m), 1.56-1.48 (6 H, m), 1.42-1.27 (18 H, m), $0.88(9 \mathrm{H}$, $\mathrm{t}, J 6.8) ; \delta_{\mathrm{C}}\left(150 \mathrm{MHz} ; \mathrm{DMSO} d_{6}\right) 125.3(\mathrm{~d}, J 9), 122.8(\mathrm{~d}$, $J$ 12), $119.4(\mathrm{q}, J 322, \mathrm{C}-\mathrm{F}), 30.3,29.6(\mathrm{~d}, J 15), 23.4(\mathrm{~d}$, $J$ 47), 21.7, 20.3 (d, $J$ 4), $17.4(\mathrm{~d}, J 47), 13.6 ; \delta_{\mathrm{P}}(121 \mathrm{MHz}$; DMSO $\left.d_{6} ; 85 \% \mathrm{H}_{3} \mathrm{PO}_{4}\right) 33.4 ; \mathrm{m} / z$ (ESI, +ve) $327.3181\{[\mathrm{M}-$ $\left.\left(\mathrm{CH}_{3} \mathrm{SO}_{2}\right)_{2} \mathrm{~N}^{-}\right]^{+}$requires 327.3175$\} ; \mathrm{m} / \mathrm{z}$ (ESI, -ve) 279.9169 $\left[\left(\mathrm{CH}_{3} \mathrm{SO}_{2}\right)_{2} \mathrm{~N}\right]^{-}$requires 279.9178 .

\section{Tri-n-hexylallylphosphonium octylsulfate (11c)}

Ionic liquid 11a (0.85 g, $2.09 \mathrm{mmol})$ and ammonium octylsulfate $(0.48 \mathrm{~g}, 2.11 \mathrm{mmol})$ gave $1.03 \mathrm{~g}(92 \%)$ of the desired product as a clear liquid; $\delta_{\mathrm{H}}\left(300 \mathrm{MHz}\right.$; DMSO $\left.d_{6}\right) 5.88-5.72(1 \mathrm{H}, \mathrm{m}), 5.46$ $5.32(2 \mathrm{H}, \mathrm{m}), 3.68(2 \mathrm{H}, \mathrm{t}, J$ 6.7), $3.22(2 \mathrm{H}, \mathrm{dd}, J 16.1$ and 7.5), $2.26-2.16(6 \mathrm{H}, \mathrm{m}), 1.55-1.45(8 \mathrm{H}, \mathrm{m}), 1.40-1.25(28 \mathrm{H}$, $\mathrm{m}), 0.90-0.84(12 \mathrm{H}, \mathrm{m}) ; \delta_{\mathrm{C}}\left(150 \mathrm{MHz}\right.$; DMSO $\left.d_{6}\right) 125.6(\mathrm{~d}, J$ 9), $122.6(\mathrm{~d}, J$ 12), 65.3, 31.2, 30.3, 29.7 (d, $J$ 15), 29.0, 28.7, 28.6, 25.5, 23.4 (d, $J$ 47), 22.0, 21.7, 20.4 (d, $J 4), 17.4$ (d, $J 47$ ), $13.7 ; \delta_{\mathrm{P}}\left(121 \mathrm{MHz}\right.$; DMSO $\left.d_{6} ; 85 \% \mathrm{H}_{3} \mathrm{PO}_{4}\right) 33.3 ; \mathrm{m} / z(\mathrm{ESI},+\mathrm{ve})$ $327.3182\left[\mathrm{M}-\left(\mathrm{C}_{8} \mathrm{H}_{17} \mathrm{OSO}_{3}^{-}\right)^{+}\right.$requires 327.3175$] ; \mathrm{m} / \mathrm{z}(\mathrm{ESI},-\mathrm{ve})$ $209.0852\left(\mathrm{C}_{8} \mathrm{H}_{17} \mathrm{OSO}_{3}\right)^{-}$requires 209.0853.

\section{Tri-n-hexyl(methoxymethyl)phosphonium triflimide (12b)}

Ionic liquid 12a (0.76 g, $2.07 \mathrm{mmol})$ and lithium triflimide $(0.65 \mathrm{~g}, 2.26 \mathrm{mmol})$ gave $1.15 \mathrm{~g}(91 \%)$ of the desired product as a clear liquid; $\delta_{\mathrm{H}}\left(300 \mathrm{MHz}\right.$; DMSO $\left.d_{6}\right) 4.37(\mathrm{~d}, J 5.2), 3.44$ (3 H, s), 2.28-2.17 (6 H, m), 1.59-1.46 (6 H, m), 1.46-1.27
$(18 \mathrm{H}, \mathrm{m}), 0.88\left(9 \mathrm{H}, \mathrm{t}, J\right.$ 6.7); $\delta_{\mathrm{C}}\left(150 \mathrm{MHz}\right.$; DMSO $\left.d_{6}\right) 119.4$ (q, $J 322, \mathrm{C}-\mathrm{F}), 61.6(\mathrm{~d}, J$ 62), $61.4(\mathrm{~d}, J 12), 30.3,29.6(\mathrm{~d}$, $J$ 15), 21.7, 20.4 (d, $J 4), 16.4$ (d, $J 46), 13.6 ; \delta_{\mathrm{P}}(121 \mathrm{MHz}$; DMSO $\left.d_{6} ; 85 \% \mathrm{H}_{3} \mathrm{PO}_{4}\right) 33.1 ; \mathrm{m} / z$ (ESI, +ve) $331.3124\{[\mathrm{M}-$ $\left.\left(\mathrm{CH}_{3} \mathrm{SO}_{2}\right)_{2} \mathrm{~N}^{-}\right]^{+}$requires 331.3124\}; $\mathrm{m} / \mathrm{z}$ (ESI, -ve) 279.9180 $\left[\left(\mathrm{CH}_{3} \mathrm{SO}_{2}\right)_{2} \mathrm{~N}\right]^{-}$requires 279.9178 .

\section{Tri-n-hexyl(methoxymethyl)phosphonium octylsulfate (12c)}

Ionic liquid 12a $(0.76 \mathrm{~g}, 2.07 \mathrm{mmol})$ and ammonium octylsulfate $(0.47 \mathrm{~g}, 2.07 \mathrm{mmol})$ gave $1.00 \mathrm{~g}(89 \%)$ of the desired product as a clear liquid; $\delta_{\mathrm{H}}\left(300 \mathrm{MHz}\right.$; DMSO $\left.d_{6}\right) 4.41(2 \mathrm{H}, \mathrm{d}, J 5.3), 3.69$ $(2 \mathrm{H}, \mathrm{t}, J$ 6.7), $3.43(3 \mathrm{H}, \mathrm{s}), 2.30-2.20(6 \mathrm{H}, \mathrm{m}), 1.58-1.49$ (8 $\mathrm{H}, \mathrm{m}), 1.40-1.25(28 \mathrm{H}, \mathrm{m}), 0.90-0.84(12 \mathrm{H}, \mathrm{m}) ; \delta_{\mathrm{C}}(150 \mathrm{MHz}$; DMSO $\left.d_{6}\right) 65.3,61.6(\mathrm{~d}, J 63), 61.3(\mathrm{~d}, J 13), 31.2,30.3,29.7(\mathrm{~d}$, $J$ 15), 29.0, 28.7, 28.6, 25.4, 22.0, 21.7, 20.4 (d, $J$ 4), 16.3 (d, $J$ 46), $13.7,13.7 ; \delta_{\mathrm{P}}\left(121 \mathrm{MHz}\right.$; DMSO $\left.d_{6} ; 85 \% \mathrm{H}_{3} \mathrm{PO}_{4}\right) 33.0 ; \mathrm{m} / z$ $(\mathrm{ESI},+\mathrm{ve}) 331.3113\left[\mathrm{M}-\left(\mathrm{C}_{8} \mathrm{H}_{17} \mathrm{OSO}_{3}^{-}\right)^{+}\right.$requires 331.3124$] ; \mathrm{m} / z$ (ESI, -ve) $209.0844\left(\mathrm{C}_{8} \mathrm{H}_{17} \mathrm{OSO}_{3}\right)^{-}$requires 209.0853.

\section{Tri-n-hexyl(2-hydroxyethyl)phosphonium triflimide (13b)}

Ionic liquid 13a (0.89 g, $2.02 \mathrm{mmol})$ and lithium triflimide $(0.64 \mathrm{~g}, 2.23 \mathrm{mmol})$ gave $1.07 \mathrm{~g}(87 \%)$ of the desired product as a clear liquid; $\delta_{\mathrm{H}}\left(300 \mathrm{MHz}\right.$; DMSO $\left.d_{6}\right) 3.77(2 \mathrm{H}, \mathrm{td}, J$ 18.7 and 6.1), $2.41(2 \mathrm{H}, \mathrm{td}, J 12.3$ and 6.1$), 2.25-2.15(6 \mathrm{H}$, m), 1.57-1.48 (6 H, m), 1.41-1.29 (18 H, m), 0.88 (9 H, t, J 6.4); $\delta_{\mathrm{C}}\left(150 \mathrm{MHz}\right.$; DMSO $\left.d_{6}\right) 119.4(\mathrm{q}, J 322, \mathrm{C}-\mathrm{F}), 54.3(\mathrm{~d}$, $J$ 6), 30.3, 29.7 (d, $J$ 15), 21.7, 21.4, 20.5 (d, $J$ 4), 18.3 (d, $J$ 47), 13.6; $\delta_{\mathrm{P}}\left(121 \mathrm{MHz}\right.$; DMSO $\left.d_{6} ; 85 \% \mathrm{H}_{3} \mathrm{PO}_{4}\right) 34.5 ; \mathrm{m} / z$ (ESI, +ve) $331.3120\left\{\left[\mathrm{M}-\left(\mathrm{CH}_{3} \mathrm{SO}_{2}\right)_{2} \mathrm{~N}^{-}\right]^{+}\right.$requires 331.3124$\}$; $\mathrm{m} / \mathrm{z}(\mathrm{ESI},-\mathrm{ve}) 279.9179\left[\left(\mathrm{CH}_{3} \mathrm{SO}_{2}\right)_{2} \mathrm{~N}\right]^{-}$requires 279.9178.

\section{Tri-n-hexyl(2-hydroxyethyl)phosphonium octylsulfate (13c)}

Ionic liquid 13a $(0.89 \mathrm{~g}, 2.02 \mathrm{mmol})$ and ammonium octylsulfate $(0.46 \mathrm{~g}, 2.02 \mathrm{mmol})$ gave $1.01 \mathrm{~g}(93 \%)$ of the desired product a clear liquid; $\delta_{\mathrm{H}}\left(300 \mathrm{MHz}\right.$; DMSO $\left.d_{6}\right) 3.82-3.66(4 \mathrm{H}, \mathrm{m}), 2.43$ $(2 \mathrm{H}, \mathrm{td}, J 12.4$ and 6.1), 2.27-2.17 (6 H, m), 1.57-1.45 (8 H, m), $1.40-1.25(28 \mathrm{H}, \mathrm{m}), 0.90-0.84(12 \mathrm{H}, \mathrm{m}) ; \delta_{\mathrm{C}}(150 \mathrm{MHz}$; DMSO $\left.d_{6}\right) 65.4,54.3(\mathrm{~d}, J$ 6), 31.2, 30.3, 29.7 (d, $J$ 16), 29.0, 28.7, 28.6, 25.5, 22.0, 21.7, 21.4, 20.5 (d, $J 4), 18.3$ (d, $J 47), 13.8$, $13.7 ; \delta_{\mathrm{P}}\left(121 \mathrm{MHz} ; \mathrm{DMSO} d_{6} ; 85 \% \mathrm{H}_{3} \mathrm{PO}_{4}\right) 34.4 ; \mathrm{m} / z$ (ESI, +ve) $331.3129\left[\mathrm{M}-\left(\mathrm{C}_{8} \mathrm{H}_{17} \mathrm{OSO}_{3}{ }^{-}\right)^{+}\right.$requires 331.3124]; $\mathrm{m} / \mathrm{z}$ (ESI, -ve) $209.0862\left(\mathrm{C}_{8} \mathrm{H}_{17} \mathrm{OSO}_{3}\right)^{-}$requires 209.0853 .

\section{ISO $14593-\mathrm{CO}_{2}$ headspace test}

To evaluate the biodegradability of the test PILs, the " $\mathrm{CO}_{2}$ headspace" test (ISO 14593, OECD 310) was applied. This method allows the evaluation of the ultimate aerobic biodegradability of an organic compound in an aqueous medium at a given concentration of microorganisms by analysis of inorganic carbon (IC). The test PIL, as the sole source of carbon and energy, was added at a concentration of 10 to $20 \mathrm{mg} \mathrm{C} / \mathrm{L}$ to a buffer-mineral salts medium. These solutions were inoculated with activated sludge collected from an activated sludge treatment plant, washed and aerated prior to use and incubated in sealed vessels with a headspace of air. Biodegradation (mineralisation to carbon dioxide) was determined by measuring the IC produced in the test bottles in excess of that produced 
in blank vessels containing inoculated medium only. Sodium $n$-dodecyl sulfate (SDS) was used as reference substance. The test ran for 28 days. The extent of biodegradation was expressed as a percentage of the theoretical amount of inorganic carbon (ThIC) based on the amount of test compound added initially.

\section{Acknowledgements}

The authors thank Pfizer Global R\&D, the Spanish Ministerio de Educación y Ciencia (CTQ2007-60364/PPQ) and the Australian Research Council (LX0561094) for financial support.

\section{Notes and references}

1 P. Walden, Bill. Acad. Impér. Sci. Pétersbourg, 1914, 8, 405422.

2 T. Welton, Chem. Rev., 1999, 99, 2071-2083.

3 J. S. Wilkes and M. J. Zaworotko, J. Chem. Soc., Chem. Commun., 1992, 965-967.

4 According to ISI Web of Science searching for ionic liquid in Topic and limiting the search to 2008, http://www.isiwebofknowledge.com.

5 K. R. Seddon, Nat. Mater., 2003, 2, 363-365.

6 (a) N. V. Plechkova and K. R. Seddon, Chem. Soc. Rev., 2008, 37, 123 150; (b) M. Maase, in Ionic Liquids in Synthesis, eds. P. Wasserscheid and T. Welton, Wiley-VCH, Weinheim, 2nd edn., 2008, vol. 2, pp. 663-687.

7 (a) Y. Ogomi, T. Kato and S. Hayase, J. Photopolym. Sci. Technol., 2006, 19, 403-408; (b) M. Gorlov and L. Kloo, Dalton Trans., 2008, 2655-2666.

8 (a) M. Zhang, V. Kamavaram and R. G. Reddy, Miner. Metall. Process, 2006, 23, 177-186; (b) J. R. Harjani, T. Friščić', L. R. MacGillivray and R. D. Singer, Inorg. Chem., 2006, 45(25), 10025; (c) J. R. Harjani, P. Naik, T. Friščić', L. R MacGillivray and R. D. Singer, Dalton Trans., 2008, 4595; (d) P. U. Naik, G. McManus, M. J. Zaworotko and R. D. Singer, Dalton Trans., 2008, 4834.

9 F. Alessandrini, G. B. Appetecchi, M. Conte and S. Passerini, ECS Trans., 2006, 1, 67-71.

10 Z. Li, J. Chang, H. Shan and J. Pan, Rev. Anal. Chem., 2007, 26, $109-153$.

11 (a) T. Welton, Coord. Chem. Rev., 2004, 248, 2459-2477; (b) I. Hemeon and R. D. Singer, Chem. Commun., 2002, 1884; (c) I. Hemeon and R. D. Singer, J. Mol. Catal. A: Chem., 2004, 214, 33.

12 J. Dupont, R. F. de Souza and P. A. Z. Suarez, Chem. Rev., 2002, 102, 3667-3692.

13 (a) M. Earle, in Ionic Liquids in Synthesis, eds. P. Wasserscheid and T. Welton, Wiley-VCH, Weinheim, 2nd edn., 2008, vol. 1, pp. 292367; (b) I. Hemeon, C. DeAmicis, H. Jenkins, P. Scammells and R. D. Singer, Synlett, 2002, 1815-1818; (c) J. K. D. Surette, L. Green and R. D. Singer, Chem. Commun., 1996, 2753-2754; (d) A. Stark, B. L. MacLean and R. D. Singer, J. Chem. Soc., Dalton Trans., 1999, 63-66.
14 M. J. Earle and K. R. Seddon, Pure Appl. Chem., 2000, 72, 13911398.

15 B. Jastorff, R. Störmann, J. Ranke, K. Mölter, F. Stock, B. Oberheitmann, W. Hoffmann, J. Hoffmann, M. Nüchter, B. Ondruschka and J. Filser, Green Chem., 2003, 5, 136-142.

16 J. Ranke, S. Stolte, R. Störmann, J. Arning and B. Jastorff, Chem. Rev., 2007, 107, 2183-2206.

17 (a) N. Gathergood and P. J. Scammells, Aust. J. Chem., 2002, 55, 557-560; (b) N. Gathergood, M. T. Garcia and P. J. Scammells, Green Chem., 2004, 6, 166-175.

18 P. Wasserscheid, R. van Hal and A. Bösmann, Green Chem., 2002, 4, 400-404.

19 M. T. Garcia, N. Gathergood and P. J. Scammells, Green Chem., $2005,7,9-14$.

20 N. Gathergood, P. J. Scammells and M. T. Garcia, Green Chem., 2006, 8, 156-160.

21 S. Bouquillon, T. Courant, D. Dean, N. Gathergood, S. Morrissey, B. Pegot, P. J. Scammells and R. D. Singer, Aust. J. Chem., 2007, 60, 843-847.

22 A. Romero, A. Santos, J. Tojo and A. Rodríguez, J. Hazard. Mater., 2008, 151, 268-273.

23 K. M. Docherty, J. K. Dixon and C. F. Kulpa Jr, Biodegradation, 2007, 18, 481-493.

24 S. Stolte, S. Abdulkarim, J. Arning, A.-K. Blomeyer-Nienstedt, U. Bottin-Weber, M. Matzke, J. Ranke, B. Jastorff and J. Thöming, Green Chem., 2008, 10, 214-224.

25 (a) J. R. Harjani, R. D. Singer, M. T. Garcia and P. J. Scammells, Green Chem., 2008, 10, 436-438; (b) J. R. Harjani, R. D. Singer, M. T. Garcia and P. J. Scammells, Green Chem., 2009, 11, 83-90.

26 G. Johnston-Hall, J. R. Harjani, P. J. Scammells and M. J. Monteiro, Macromolecules, 2009, 42, 1604-1609.

27 M. Stasiewicz, E. Mulkiewicz, R. Tomczak-Wandzel, J. Kumirska, E. M. Siedlecka, M. Gołebiowski, J. Gajdus, M. Czerwicka and P. Stepnowski, Ecotoxicol. Environ. Saf., 2008, 71, 157-165.

28 T. P. T. Pham, C.-W. Cho, C.-O. Jeon, Y.-J. Chung, M.-W. Lee and Y.-S. Yun, Environ. Sci. Technol., 2009, 43, 516-521.

29 J. R. Harjani, J. Farrell, M. T. Garcia, R. D. Singer and P. J. Scammells, Green Chem., 2009, 11, 821-829.

30 Y. Yu, X. Lu, Q. Zhou, K. Dong, H. Yao and S. Zhang, Chem.-Eur. J., 2008, 14, 11174-11182.

31 (a) C. J. Bradaric, A. Downard, C. Kennedy, A. J. Robertson and Y. Zhou, Green Chem., 2003, 5, 143-152; (b) P. J. Scammells, J. L. Scott and R. D. Singer, Aust. J. Chem., 2005, 58, 155-169; (c) S. T. Handy, Curr. Org. Chem., 2005, 9, 959-988; (d) G. Keglevich, Z. Baán, I. Hermecz, T. Novák and I. L. Odinets, Curr. Org. Chem., 2007, 11, $107-126$.

32 A. S. Wells and V. T. Coombe, Org. Process Res. Dev., 2006, 10, 794-798.

33 R. S. Boethling, E. Sommer and D. DiFiore, Chem. Rev., 2007, 107, 2207-2227.

34 (a) C. G. Van Ginkel, in Biodegradability of Surfactants, eds. D. R. Karsa and M. R. Porter, Blackie Academic \& Professional, 1995, pp. 183-203; (b) M. T. Garcia, I. Ribosa, T. Guindulain, J. Sanchez-Leal and J. Vives-Rego, Environ. Pollut., 2001, 111, 169175. 